\title{
Non-parametric Test Analysis on a Questionnaire Investigation for Rare Sugars
}

\author{
Yasuo Ishii ${ }^{1}$, Hiromasa Takeyasu ${ }^{2}$, Daisuke Takeyasu ${ }^{3} \&$ Kazuhiro Takeyasu $^{4}$ \\ ${ }^{1}$ Yamato University, Japan \\ ${ }^{2}$ Kagawa Junior College, Utazu, Kagawa, Japan \\ ${ }^{3}$ The Open University of Japan, Japan \\ ${ }^{4}$ Tokoha University, Hamamatsu, Japan \\ Correspondence: Kazuhiro Takeyasu, Tokoha University, Hamamatsu, Japan.
}

Received: June 16, 2018

doi:10.5430/ijba.v9n4p127
Accepted: July 5, 2018

Online Published: July 18, 2018

URL: https://doi.org/10.5430/ijba.v9n4p127

\begin{abstract}
The Rare Sugars exist naturally and have many kinds (more than 50). They have good effect for health such as prevention of increasing the blood-sugar level after eating, suppression of fat accumulation, suppression of increasing the blood pressure, and anti-oxidative effect etc. It is in the spotlight for many people especially for those who are in the metabolic syndrome. There are few related papers concerning the marketing research and its utilization of this matter. In this paper, a questionnaire investigation is executed to the student of Kagawa Junior College in order to clarify consumers' current condition and their consciousness, and to seek the possibility of utilizing the Rare Sugars. Fundamental statistical analysis and Non-Parametric Test Analysis are performed. Some interesting and instructive results were obtained.
\end{abstract}

Keywords: rare sugars, health, consumer, non-parametric test

\section{Introduction}

The Rare Sugars' study has launched on $1980^{\text {th }}$ by Professor Takeshi Izumori (Kagawa University). The way to the mass production was developed by the method of enzymatic reaction. The International Society of Rare Sugars was established in 2001. Local government of Kagawa Prefecture comes to assist this research activity on this big innovation newly born in Kagawa Prefecture. The Rare Sugars have advantage that a blood-sugar level does not increase so much after eating, in spite of it being a sugar. And it also holds the upturn of the blood pressure. Therefore it is expected as a new functional material for the prevention of metabolic syndrome.

By the way, one kind of the Rare Sugar D-psicose has the following characteristics.

(1) a sweetening made by the natural starch

(2) non calorie and its sweetness is $70 \%$ to those of sugar

(3) organoleptic property of coolness and sharpness in taste

Many medical research papers are published on the Rare Sugars as follows.

Analysis of the function of D-psicose; (Hossain, M.A., et al., 2011; Hayashi, N., et al., 2010; Iida, T., et al., 2010; Miyanishi, N., et al., 2008; Suna, S., et al., 2007; Murao, K., et al., 2007)

Analysis of the function of D-allose; (Yamada, K., et al., 2012; Nakamura, T., et al., n.d.; Kajikawa, T., et al., 2010; Hirata, Y., et al., 2009; Mitani, T., et al., 2009; Yamaguchi, F., et al., 2008; Yamaguchi, F., et al., 2008; Sui, L., et al., 2007)

On the other hand, these are few papers analyzed by the viewpoint from consumers. The Rare Sugars is good for the health and is sold in the market as a sweetening, seasoning or functional ingredient for food.

In this paper, a questionnaire investigation is executed to the student of Kagawa Junior College in order to clarify the recognition level among consumers and to pursue the future possibility of the Rare Sugars. Basic statistical analysis and Non-Parametric Test are conducted. 
The rest of this paper is organized as follows. In section 2, outline of the questionnaire investigation and its basic statistical results are exhibited. After that, Non-Parametric Test is performed in section 3, which is followed by the conclusion of section 4.

\section{Outline and the Basic Statistical Results of the Questionnaire Research}

\subsection{Outline of the Questionnaire Research}

A questionnaire investigation is executed to the student of Kagawa Junior College in order to clarify the recognition level among consumers and to pursue the future possibility of the Rare Sugars. The outline of the questionnaire research is as follows. The questionnaire sheet is attached in Appendix.
(1) Scope of investigation
(2) Period
(3) Method
Student of Kagawa Junior College
April-June 2015
(4) Collection
: Leave until called for
Number of collection 186 (collection rate 100.0\%)
Valid answer 186
: Number of distribution 186

\subsection{Basic Statistical Results}

Now, we show the main summary results by single variable.

Table 1 . The main summary results by single variable

\begin{tabular}{llcc}
\hline & & Answerers & Share (\%) \\
\hline \multirow{4}{*}{ Q32 Sex } & Male & 19 & 11.0 \\
& Female & 154 & 89.0 \\
& Total & 173 & 100.0 \\
\hline \multirow{5}{*}{ Q33 Age } & 19 & 139 & 80.3 \\
& $20 \sim 29$ & 33 & 19.1 \\
& $50 \sim 59$ & 1 & 0.6 \\
& Total & 173 & 100.0 \\
\hline \multirow{5}{*}{ Q34 Occupation } & Student & 171 & 98.8 \\
& Housewife & 1 & 0.6 \\
& Not filled in & 1 & 0.6 \\
& Total & 173 & 100.0 \\
\hline \multirow{5}{*}{ Q25 Do you take interest } & Think it very much & 65 & 38.0 \\
& Slightly think so & 52 & 30.4 \\
& Cannot say either & 24 & 14.0 \\
& Slightly do not think so & 15 & 8.8 \\
& Do not think so & 15 & 8.8 \\
& Total & 171 & 100 \\
\hline \multirow{5}{*}{ Q26 Are you careful for } & Think it very much & 21 & 12.2 \\
the health? & Slightly think so & 64 & 37.4 \\
& Cannot say either & 65 & 38.0 \\
& Slightly do not think so & 15 & 8.8 \\
& Do not think so & 6 & 3.5 \\
& Total & 171 & 100 \\
\hline
\end{tabular}


(1) Q1 Do you know the Rare Sugars?

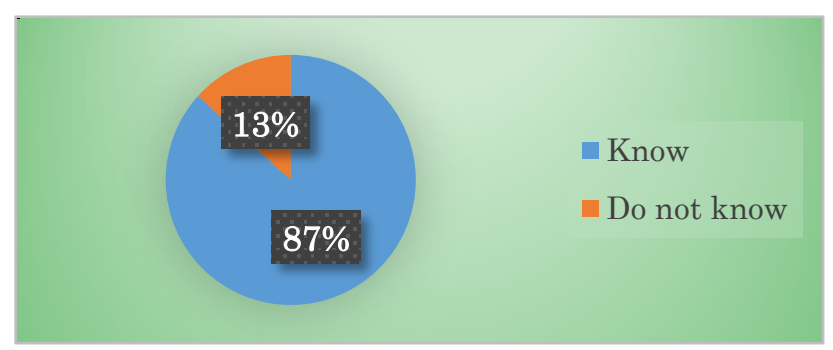

Figure 1. Q1 Do you know the Rare Sugars?

(2) Q6 Have you drunk or eaten the food which includes the Rare Sugar?

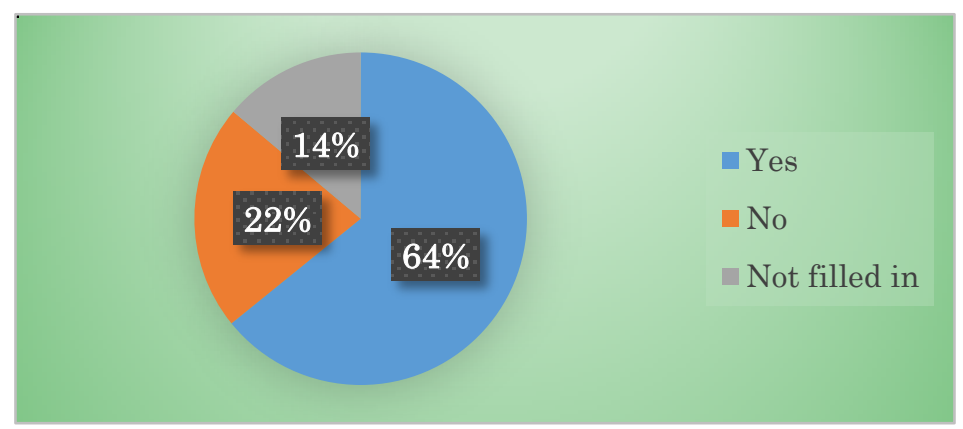

Figure 2. Q6 Have you drunk or eaten the food which includes the Rare Sugar?

(3) Q7 Was the Rare Sugar effective after using it for more than one month?

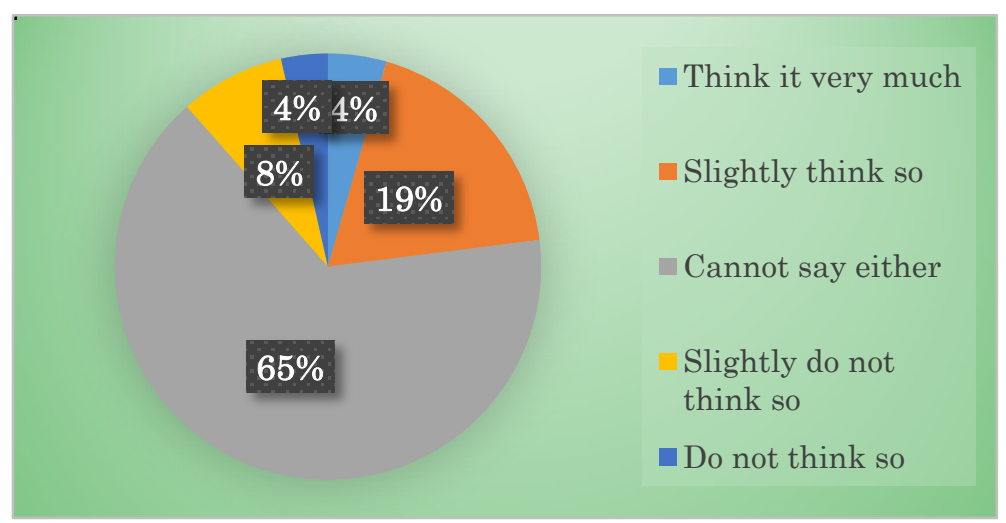

Figure 3. Q7 Was the Rare Sugar effective after using it for more than one month? 
(4) Q8 Do you want to try to eat or drink the food in which the Rare Sugar is included?

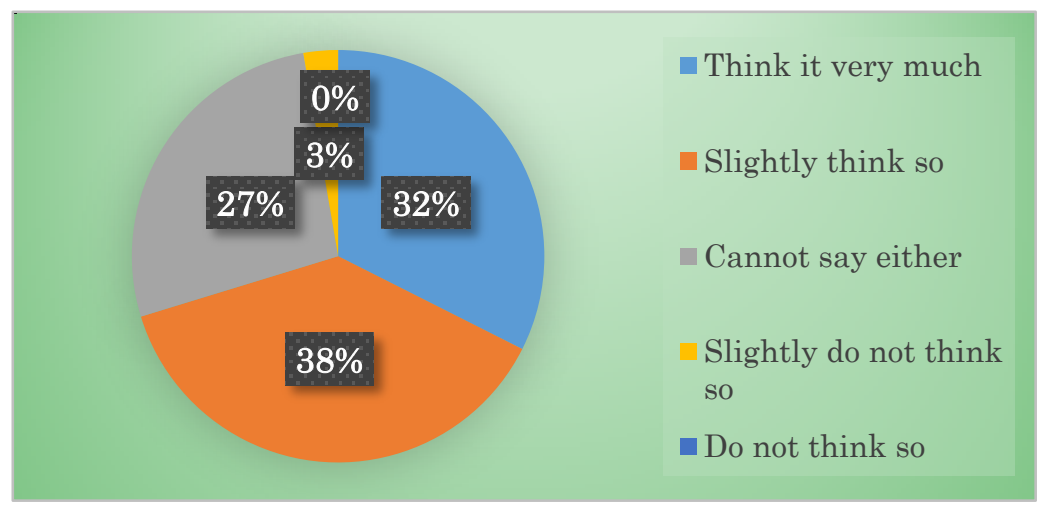

Figure 4. Q8 Do you want to try to eat or drink the food in which the Rare Sugar is included?

(5) Q10-15 How do you want to use the Rare Sugar?

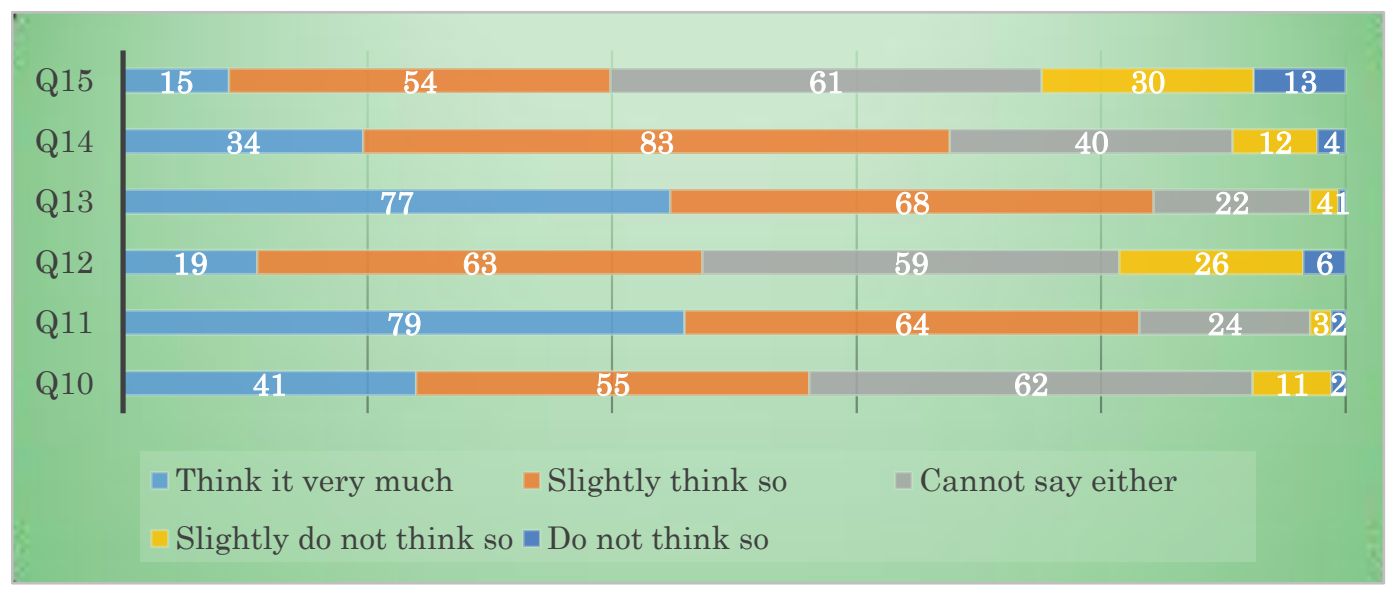

Figure 5. Q10-15 How do you want to use the Rare Sugar?

(6) Q16-22 Do you have a question (doubt) or anxiety for the Rare Sugar?

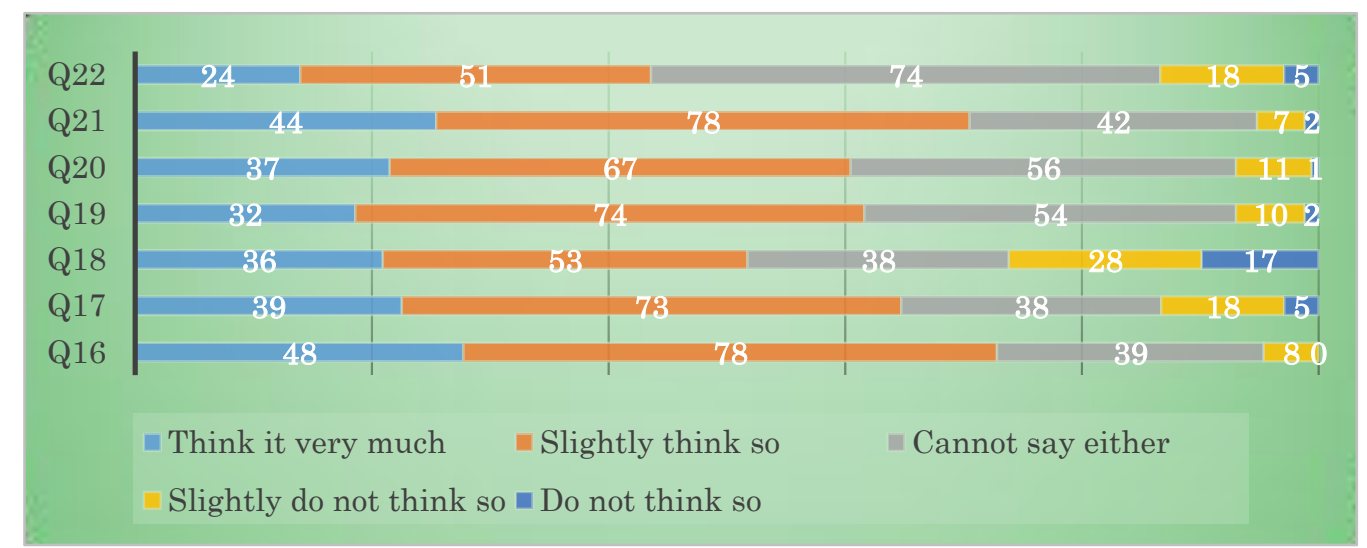

Figure 6. Q16-22 Do you have a question (doubt) or anxiety for the Rare Sugar? 


\section{Non-parametric Test}

Non-Parametric Test is executed concerning Q25 "Do you take interest in a diet?", Q26 “Are you careful for the health?" and Q27 "Do you take interest in the designated health food?". Cross tabulation is calculated for the items of Q32 "Sex", Q33 "Age” and Q36 "Lifestyle".

Significance probability is calculated as Table $2 \sim$ Table 4 for each case. Hatched parts in Table $2 \sim$ Table 4 are the Null Hypothesis rejected cases under 5\% $\left(*^{1}\right)$ or $10 \%\left(*^{2}\right)$ significance level.

As Q7 Q8、Q10 Q22 are under ordinal scale, Kruskal Wallis Test is examined, which reflects order information. $\chi^{2}$ Test is executed to $\mathrm{Q} 1 \cdot \mathrm{Q} 3 \sim \mathrm{Q} 6$ as they are under nominal scale.

Table 2. Relation with the Rare Sugar

\begin{tabular}{|c|c|c|c|c|c|c|c|c|}
\hline & & \multirow[t]{2}{*}{ Item } & \multicolumn{6}{|c|}{ Relation with the Rare Sugar } \\
\hline & & & Q1 & Q3 & Q4 & Q5 & Q6 & Q7 \\
\hline & & & $\begin{array}{c}\text { Know the } \\
\text { Rare } \\
\text { Sugar }\end{array}$ & $\begin{array}{c}\text { Know its } \\
\text { effectiveness }\end{array}$ & $\begin{array}{l}\text { Heard or used the } \\
\text { syrup which } \\
\text { includes Rare Sugar } \\
\text { "Rare Sugar Sweet" }\end{array}$ & $\begin{array}{l}\text { Have used } \\
\text { the Rare } \\
\text { Sugar }\end{array}$ & $\begin{array}{l}\text { Have eaten or } \\
\text { drunk the food in } \\
\text { which the Rare } \\
\text { Sugar is included }\end{array}$ & $\begin{array}{l}\text { Effect of the } \\
\text { Rare Sugar }\end{array}$ \\
\hline Concern & Q25 & Diet & 0.405 & 0.157 & 0.252 & 0.9 & 0.604 & 0.742 \\
\hline Attribute & Q32 & Sex & $0.009 *^{1}$ & 0.16 & 0.474 & 0.254 & 0.967 & $0.076 *^{2}$ \\
\hline and & Q33 & Age & 0.9 & 0.486 & 0.27 & 0.585 & 0.714 & 0.218 \\
\hline Lifestyle & Q36 & Lifestyle & 0.225 & 0.944 & 0.936 & $0.092 *^{2}$ & 0.244 & 0.329 \\
\hline
\end{tabular}

From Figure 1, we can observe that the evaluation of Q7 "Effect of the Rare Sugar" is different by the degree of Q26 "Careful for the health" and we can also confirm that Q4 "Awareness of the "Rare Sugar Sweet"” is different by the degree of interest in the designated health food (Q27).

We can also find that there is a difference in the evaluation of Q1 "Do you know the Rare Sugars?" and Q7 "Was the Rare Sugar effective after using it for more than one month?" by the Sex (Q32). Moreover we can find that there is a difference in Q5 "Have you drunk or eaten the food which includes the Rare Sugar?" by the difference of Q36 "Lifestyle".

Next, we show the graphical charts in which the Null Hypothesis rejected cases under 5\% significance level.

(1) Q1 Do you know the Rare Sugars?

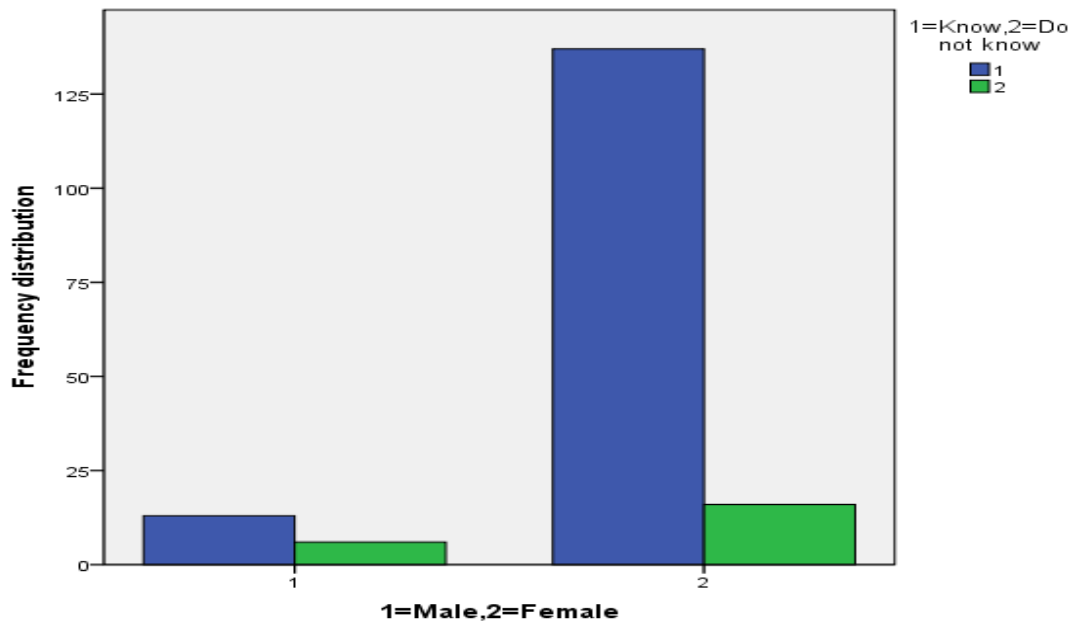

Figure 7. Do you know the Rare Sugars?-By sex 
Female is dominant.

(2) Q4 Have you heard or used the syrup which includes Rare Sugar "Rare Sugar Sweet"?

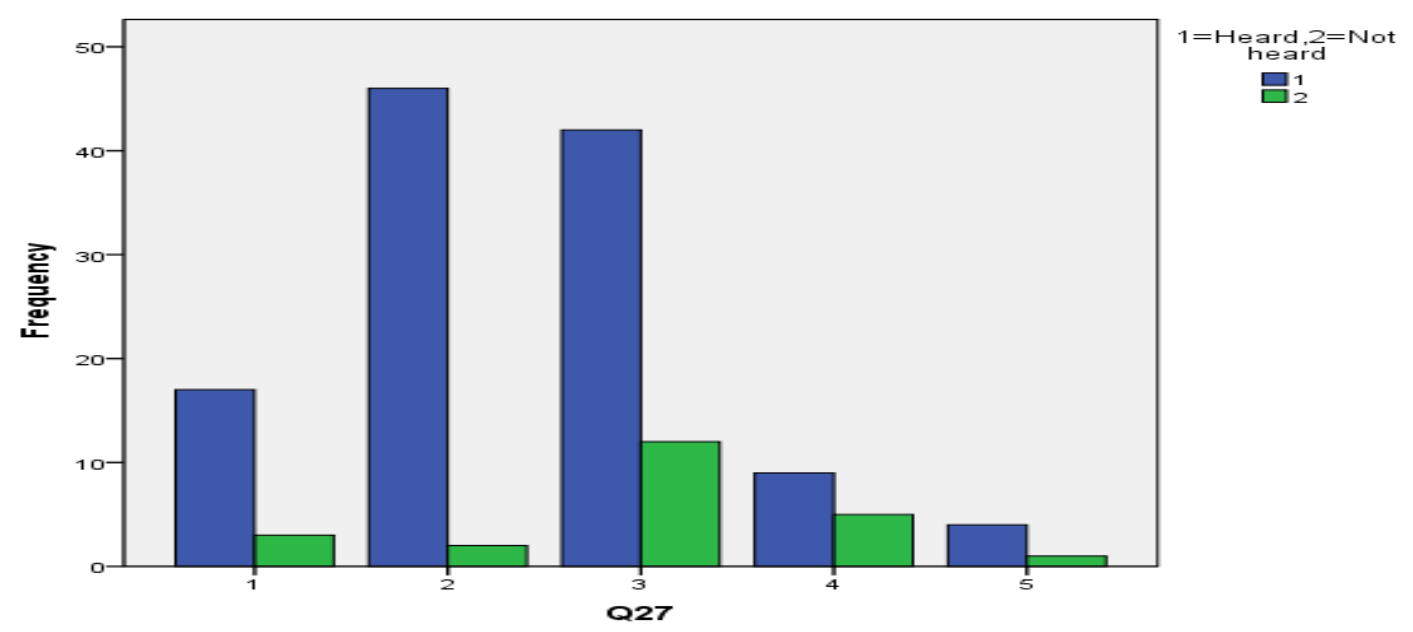

Figure 8. Have you heard or used the syrup which includes Rare Sugar "Rare Sugar Sweet"?-By the degree of interest in the designated health food

Those who have interest in the designated health food have heard or used the syrup which includes Rare Sugar "Rare Sugar Sweet".

(3) Q7 Was the Rare Sugar effective after using it for more than one month?

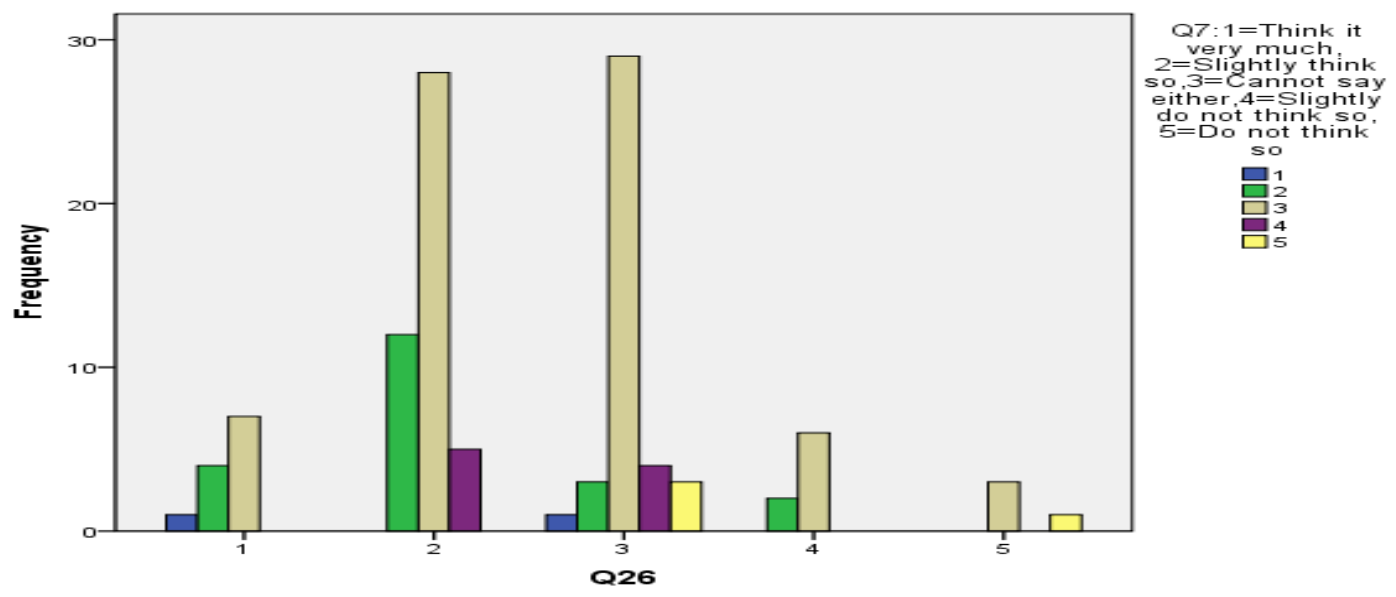

Figure 9. Was the Rare Sugar effective after using it for more than one month? By the degree of interest for the health

Those who have interest for the health evaluate the effectiveness of the Rare Sugar.

\subsection{Q8-15 What Kind of Food Do You Want to Eat if the Rare Sugar Is Included?}

For about the needs and the requirement about how to use the Rare Sugar, Q25 "Diet", Q26 "Health", Q27 "Designated Health Food", Q32 "Sex", Q33 “Age”, Q36" Lifestyle” are placed and made crosstabs. Hypothesis Testing is executed for each case (Table 3). 
Table 3. Needs and requirement about how to use the Rare Sugar

\begin{tabular}{|c|c|c|c|c|c|c|c|c|c|}
\hline & & \multirow[t]{2}{*}{ Item } & \multicolumn{7}{|c|}{ Needs and requirement about how to use the Rare Sugar } \\
\hline & & & Q8 & Q10 & Q11 & Q12 & Q13 & Q14 & Q15 \\
\hline \multirow{4}{*}{ Concern } & & & $\begin{array}{l}\text { Want to } \\
\text { eat and } \\
\text { drink the } \\
\text { Rare } \\
\text { Sugar }\end{array}$ & $\begin{array}{l}\text { Want to use } \\
\text { the Rare } \\
\text { Sugar in the } \\
\text { cooking }\end{array}$ & $\begin{array}{l}\text { Can } \\
\text { easily } \\
\text { use it if } \\
\text { there is } \\
\text { a recipe }\end{array}$ & $\begin{array}{l}\text { Want to know } \\
\text { where I can } \\
\text { buy it because } \\
\text { I want to use it } \\
\text { as a seasoning }\end{array}$ & $\begin{array}{l}\text { Want to know } \\
\text { where I can get } \\
\text { information } \\
\text { because I want } \\
\text { to use it as a } \\
\text { supplement }\end{array}$ & $\begin{array}{l}\text { Want to know } \\
\text { the hospital } \\
\text { where the Rare } \\
\text { Sugar is used as } \\
\text { a tool for } \\
\text { treatment }\end{array}$ & $\begin{array}{l}\text { Want to know } \\
\text { how long I } \\
\text { should use it } \\
\text { in order to } \\
\text { confirm the } \\
\text { effectiveness }\end{array}$ \\
\hline & Q25 & Diet & 0.163 & $0.015 *^{1}$ & 0.251 & 0.13 & $0.002 *^{1}$ & $0.091 *^{2}$ & 0.902 \\
\hline & Q26 & Health & 0.137 & $0.036 *^{1}$ & 0.325 & $0.016 *^{1}$ & 0.106 & $0.024 *^{1}$ & 0.151 \\
\hline & Q27 & $\begin{array}{l}\text { Designated } \\
\text { Health Food }\end{array}$ & $0.046 *^{1}$ & $0.001 *^{1}$ & $\begin{array}{r}0.042 \\
*^{1}\end{array}$ & 0.99 & 0.287 & 0.526 & 0.171 \\
\hline \multirow{3}{*}{$\begin{array}{l}\text { Attribute } \\
\text { and } \\
\text { Lifestyle }\end{array}$} & Q32 & Sex & 0.153 & 0.713 & 0.191 & 0.804 & 0.798 & 0.753 & 0.513 \\
\hline & Q33 & Age & 0.113 & 0.65 & $\begin{array}{r}0.031 \\
*^{1}\end{array}$ & 0.749 & 0.521 & 0.116 & 0.651 \\
\hline & Q36 & Lifestyle & 0.152 & 0.535 & 0.772 & 0.596 & 0.232 & 0.745 & 0.829 \\
\hline
\end{tabular}

From Table 3, we can observe that such users requests as Q10 "Want to use it in the cooking", Q13 "Want to know where I can get information because I want to use it as a supplement", Q14 "Want to know the hospital where the Rare Sugar is used as a tool for treatment" are different by the degree of interest for diet (Q25). And we can observe that such users' requests as Q10 "Want to use it in the cooking", Q12 "Want to know where I can buy it because I want to use it as a seasoning", Q14 "Want to know the hospital where the Rare Sugar is used as a tool for treatment" are different by the degree of interest for the health $(\mathrm{Q} 26)$. We can also find that there is a difference among Q8 "Want to try to eat or drink the food in which the Rare Sugar is included", Q10 "Want to use it in the cooking", Q11 "Can easily use it if there is a recipe" by the degree of interest in the designated health food (Q27).

As for the attribute, there is a difference in Q11 "Can easily use it if there is a recipe" by the difference of age (Q33).

Next, we show the graphical charts in which the Null Hypothesis rejected cases under 5\% significance level.

(1) Q8 Want to try to eat or drink the food in which the Rare Sugar is included-By the degree of interest in the designated health food

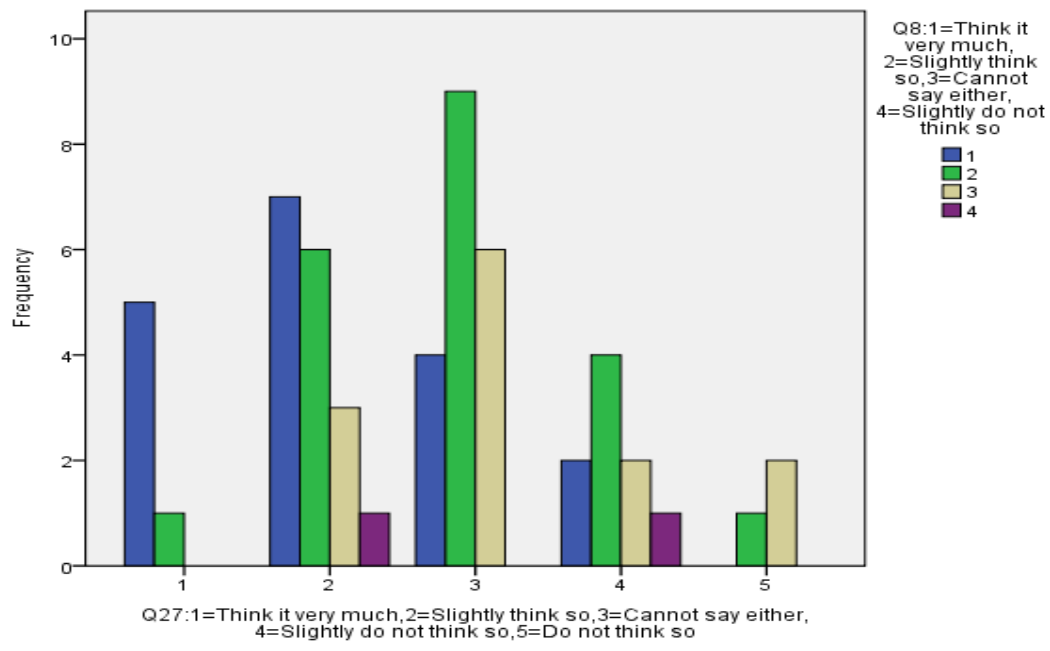

Figure 10. Q8 Want to try to eat or drink the food in which the Rare Sugar is included-By the degree of interest in the designated health food

Those who have in the designated health food want to try to eat or drink the food in which the Rare Sugar is 
included-By the degree of interest

(2) Q10 Want to use the Rare Sugar in the cooking-By the degree of interest for the diet

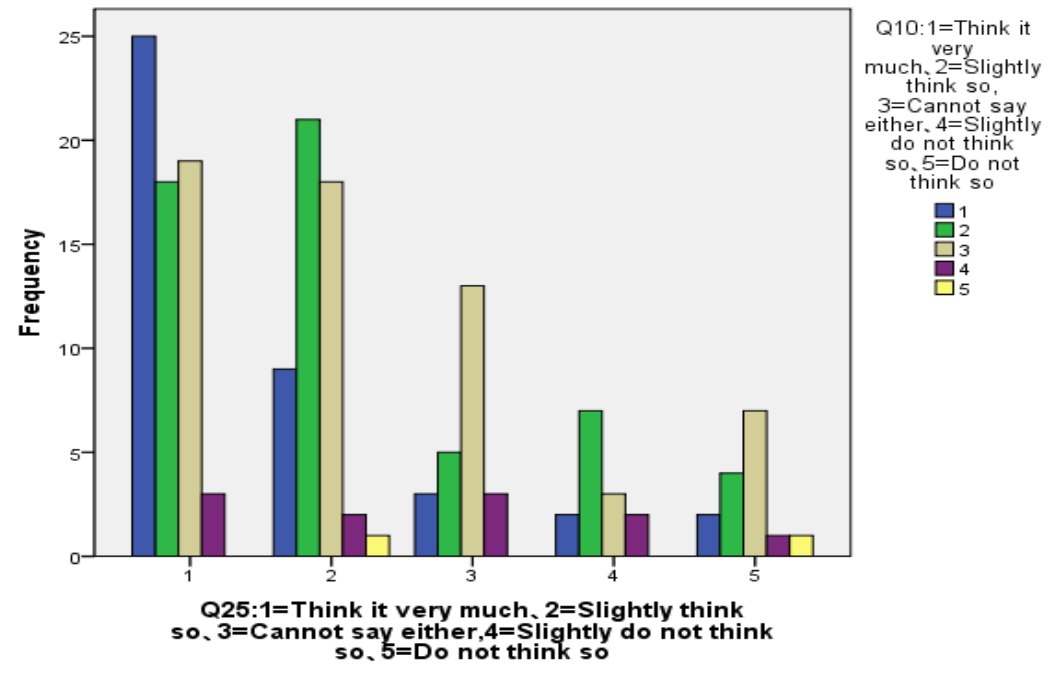

Figure 11. Q10 Want to use the Rare Sugar in the cooking - By the degree of interest for the diet

Those who have interest for the diet want to use the Rare Sugar in the cooking.

(3) Q10 Want to use the Rare Sugar in the cooking-By the degree of interest for the health

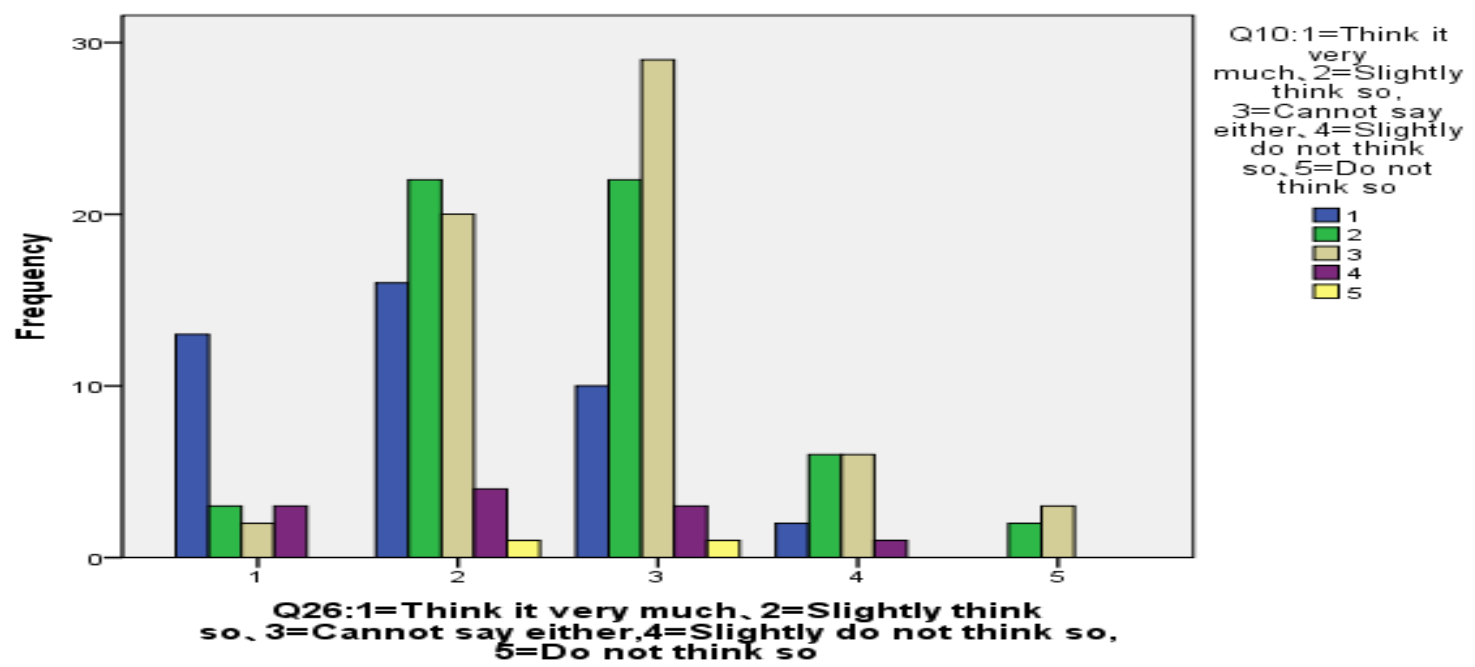

Figure 12. Q10 Want to use the Rare Sugar in the cooking-By the degree of interest for the health

Those who have interest for the health want to use the Rare Sugar in the cooking. 
(4) Q10 Want to use the Rare Sugar in the cooking- By the degree of interest in the designated health food

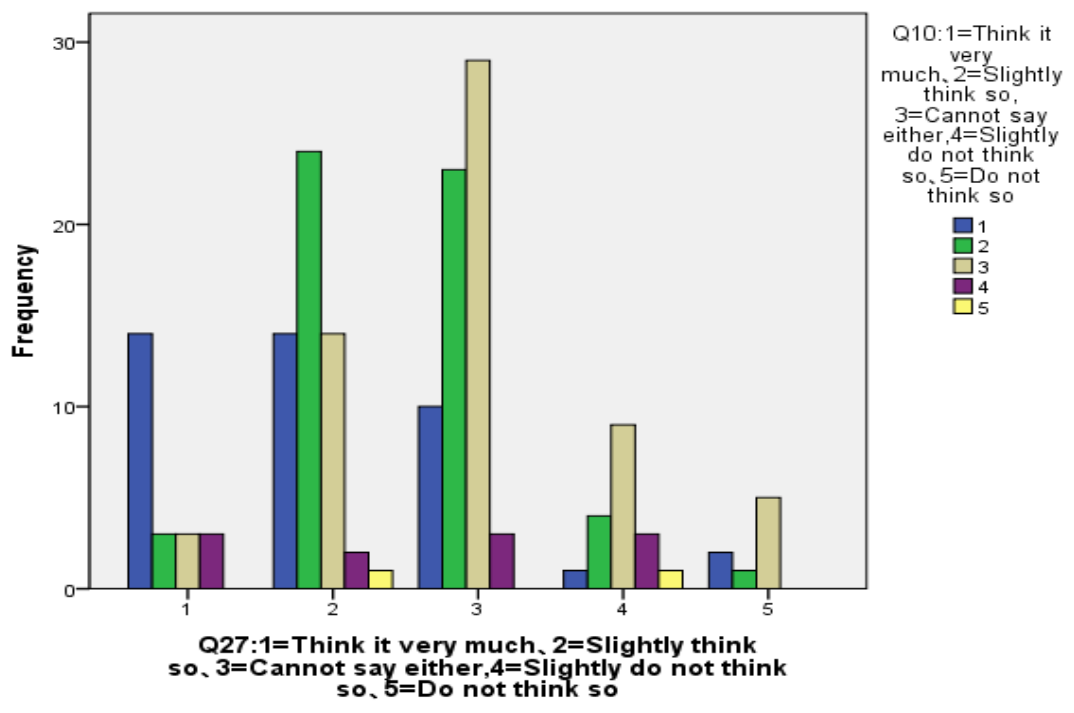

Figure 13. Q10 Want to use the Rare Sugar in the cooking- By the degree of interest in the designated health food

Those who have interest in the designated health food want to use the Rare Sugar in the cooking.

(5) Q11 Can easily use it if there is a recipe-By the degree of interest in the designated health food

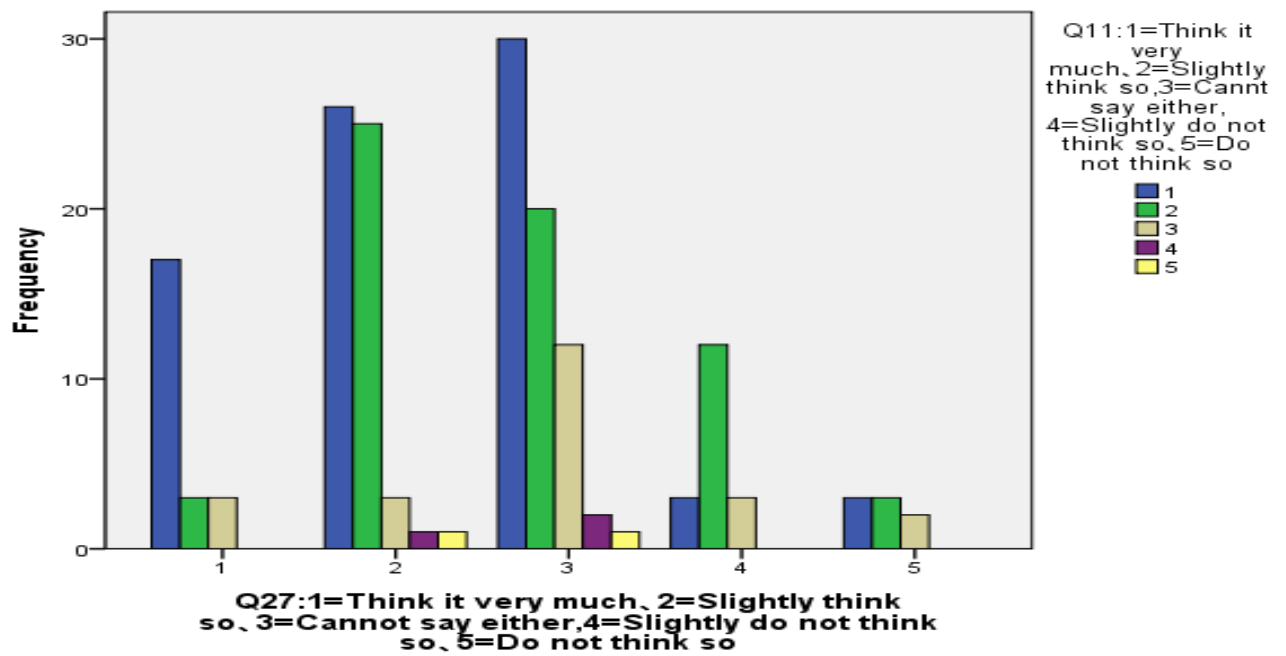

Figure 14. Q11 Can easily use it if there is a recipe-By the degree of interest in the designated health food

Those who have interest in the designated health food can easily use it if there is a recipe. 
(6) Q11 Can easily use it if there is a recipe-By age

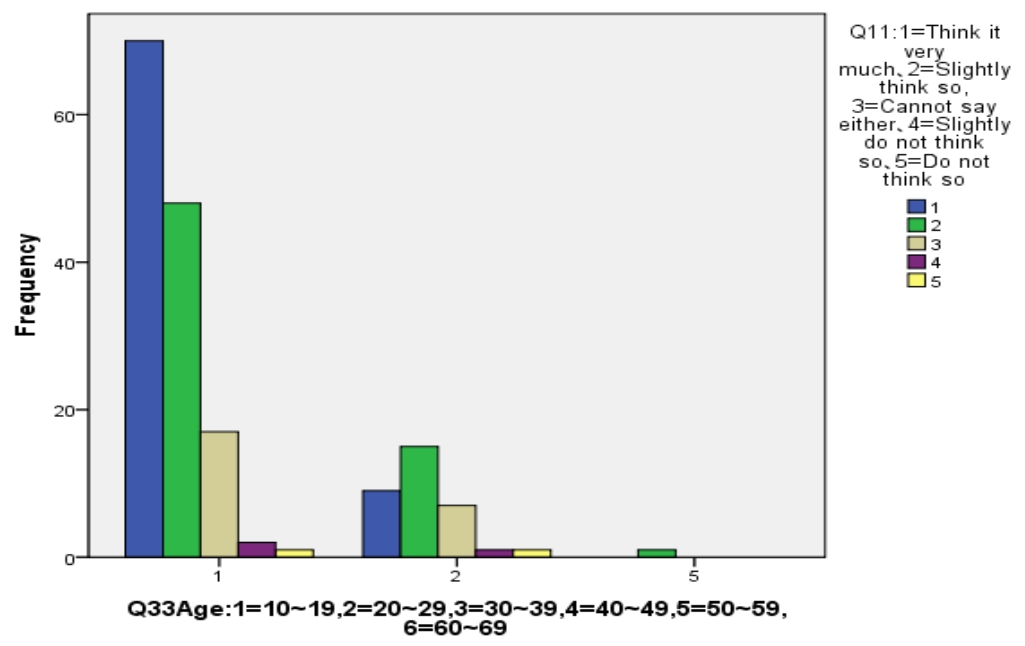

Figure 15. Q11 Can easily use it if there is a recipe-By age

Those who are $10^{\text {th }}$ can easily use it if there is a recipe.

(7) Q12 Want to know where I can buy it because I want to use it as a seasoning - By the degree of interest for the health

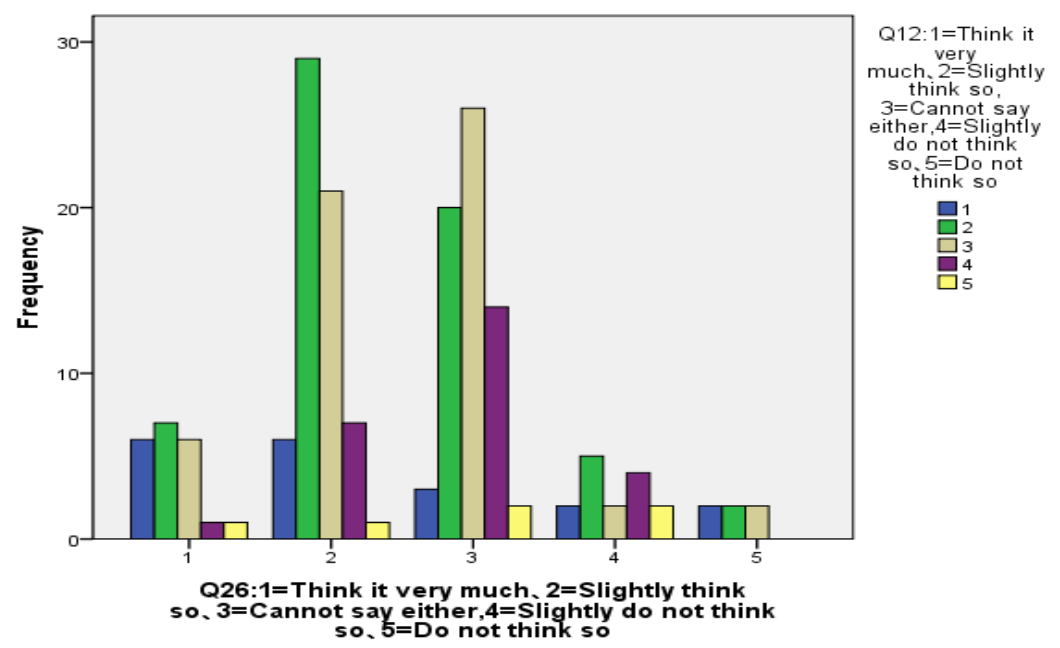

Figure 16. Q12Want to know where I can buy it because I want to use it as a seasoning-By the degree of interest for the health

Those who have interest for the health want to know where they can buy it because they want to use it as a seasoning. 
(8) Q13 Want to know where I can get information because I want to use it as a supplement-By the degree of interest for the diet

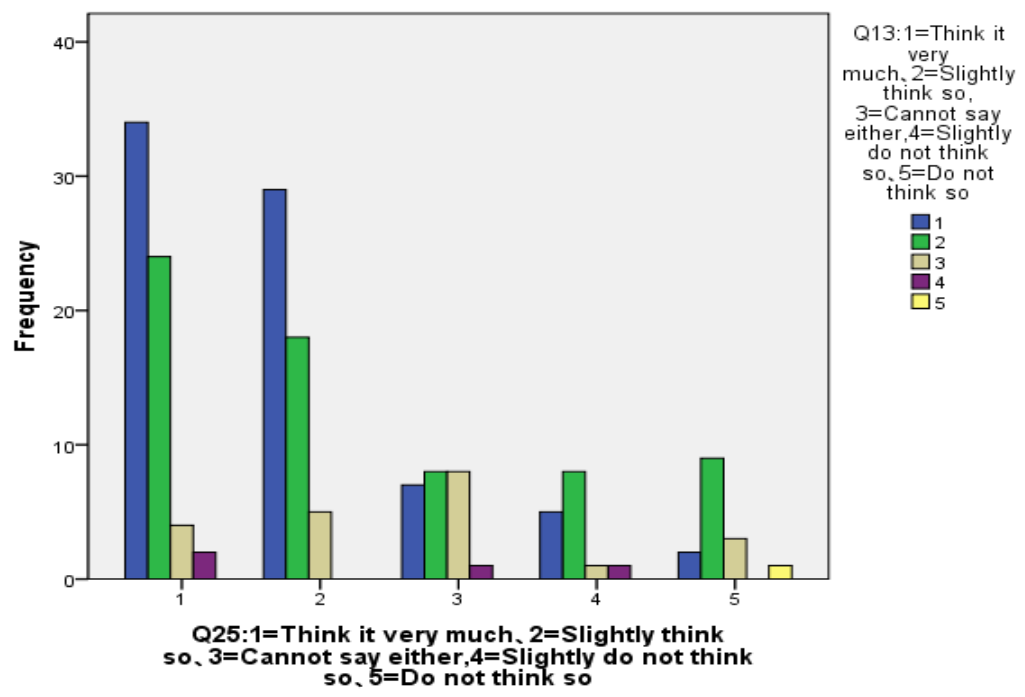

Figure 17. Q13 Want to know where I can get information because I want to use it as a supplement-By the degree of interest for the diet

Those who have interest for the diet want to know where they can get information because they want to use it as a supplement.

(9) Q14 Want to know the hospital where the Rare Sugar is used as a tool for treatment- By the degree of interest for the health

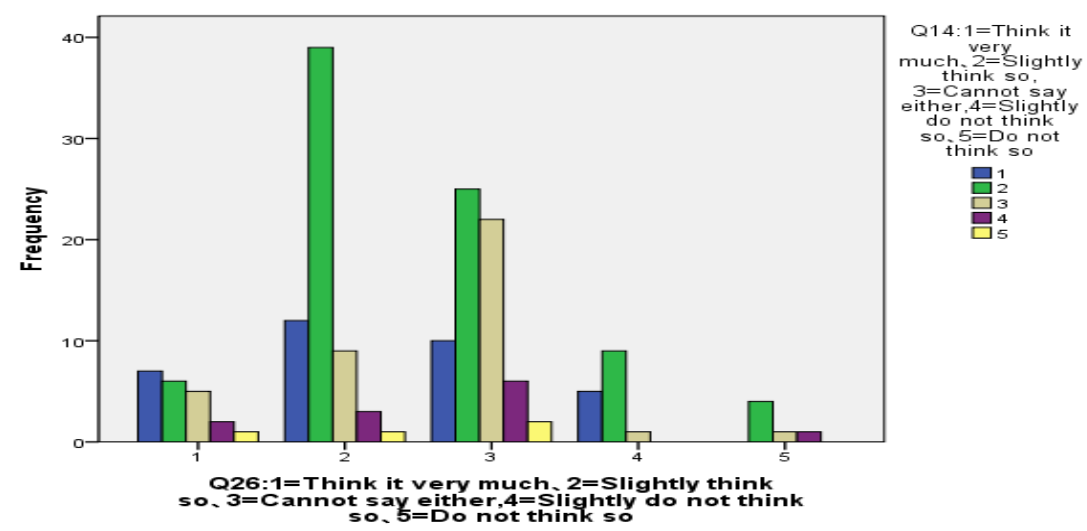

Figure 18. Q14 Want to know the hospital where the Rare Sugar is used as a tool for treatment-By the degree of interest for the health

Those who have interest for the health want to know the hospital where the Rare Sugar is used as a tool for treatment.

\subsection{Q16 23 Do You Have a Question (Doubt) or Anxiety for the Rare Sugar?}

For about the question(doubt) or anxiety for the Rare Sugar, Q25 "Diet", Q26 "Health", Q27 "Designated Health Food", Q32 "Sex", Q33 “Age", Q36" Lifestyle" are placed and made crosstabs. Hypothesis Testing is executed for each case (Table 4). 
Table 4. Do you have a question(doubt) or anxiety for the Rare Sugar?

\begin{tabular}{|c|c|c|c|c|c|c|c|c|c|}
\hline & & Item & & & questio & (doubt) or an & ety for the Rar & Sugar & \\
\hline & & & Q16 & Q17 & Q18 & Q19 & Q20 & Q21 & Q22 \\
\hline & & & $\begin{array}{l}\text { Not so } \\
\text { popular }\end{array}$ & $\begin{array}{l}\text { Seems to be } \\
\text { expensive }\end{array}$ & $\begin{array}{l}\text { Cannot } \\
\text { grasp the } \\
\text { concrete } \\
\text { effect }\end{array}$ & $\begin{array}{l}\text { Cannot } \\
\text { have } \\
\text { confidence } \\
\text { that it is } \\
\text { safe for } \\
\text { anybody }\end{array}$ & $\begin{array}{l}\text { Surrounding } \\
\text { people do } \\
\text { not use it so } \\
\text { often }\end{array}$ & $\begin{array}{l}\text { Cannot find the } \\
\text { food in the shop } \\
\text { in which the } \\
\text { Rare Sugar is } \\
\text { included }\end{array}$ & $\begin{array}{l}\text { Cannot guess how } \\
\text { I should use the } \\
\text { Rare Sugar to } \\
\text { what kind of } \\
\text { cooking }\end{array}$ \\
\hline Concern & Q25 & Diet & 0.138 & $0.009 *^{1}$ & 0.701 & $0.022 *^{1}$ & $0.008 *^{1}$ & $0.014 *^{1}$ & $0.05 *^{1}$ \\
\hline COHCEIII & Q26 & Health & $0.017 *^{1}$ & 0.146 & 0.4 & $0.029 *^{1}$ & $0.051 *^{2}$ & 0.11 & $0.001 *^{1}$ \\
\hline & Q27 & $\begin{array}{l}\text { Designated } \\
\text { Health Food }\end{array}$ & 0.498 & 0.885 & 0.772 & 0.895 & 0.74 & 0.958 & $0.077 *^{2}$ \\
\hline Attribute & Q32 & Sex & $0.043 *^{1}$ & 0.121 & $0.002 *^{1}$ & 0.127 & 0.215 & 0.281 & $0.004 *^{1}$ \\
\hline & Q33 & Age & 0.194 & $0.011 *^{1}$ & 0.176 & 0.569 & 0.561 & 0.366 & 0.297 \\
\hline $\begin{array}{l}\text { and } \\
\text { Lifestyle }\end{array}$ & Q36 & Lifestyle & 0.242 & 0.333 & 0.125 & 0.73 & 0.417 & 0.501 & 0.422 \\
\hline
\end{tabular}

From Table 4, we can observe that such users requests as Q17 "Seems to be expensive", Q19 "Cannot have confidence that it is safe for anybody", Q20 "Surrounding people do not use it so often", Q21 "Cannot find the food in the shop in which the Rare Sugar is included", Q22 "Cannot guess how I should use the Rare Sugar to what kind of cooking" are different by the degree of interest for diet (Q25). We can also find that there is a difference among Q16 "Not so popular", Q19 "Cannot have confidence that it is safe for anybody", Q20 "Surrounding people do not use it so often", Q22 "Cannot guess how I should use the Rare Sugar to what kind of cooking" by the degree of interest in the designated health food (Q26). Moreover we can also find that there is a difference in Q22 "Cannot guess how I should use the Rare Sugar to what kind of cooking" by the degree of interest for the health (Q27). And we can also find that there is a difference among Q16 "Not so popular", Q18 "Cannot grasp the concrete effect", Q22 "Cannot guess how I should use the Rare Sugar to what kind of cooking" by the sex (Q32).

As for the attribute, there is a difference in Q17 "Seems to be expensive" by the difference of age (Q33).

Next, we show the graphical charts in which the Null Hypothesis rejected cases under 5\% significance level.

a) Q16 Not so popular-By the degree of interest for the health

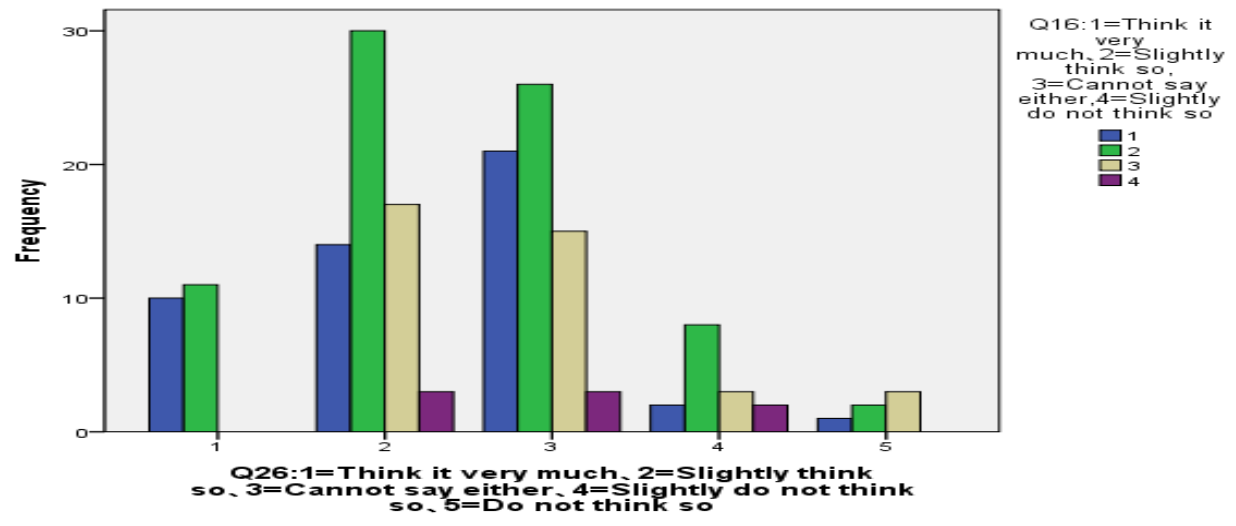

Figure 19. Q16 Not so popular-By the degree of interest for the health

Those who have interest for the health feel anxiety that it is not so popular. 
b) Q16 Not so popular-By Sex

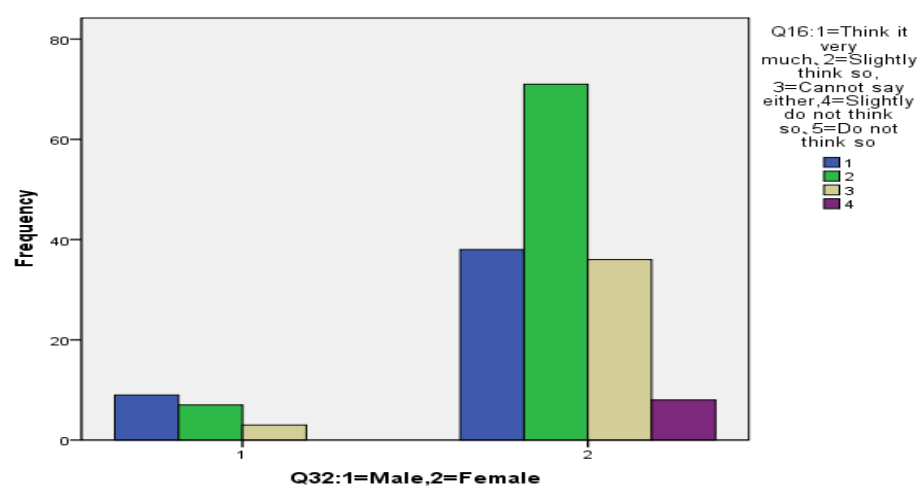

Figure 20. Q16 Not so popular-By Sex

Those who are male feel anxiety that it is not so popular.

c) Q17 Seems to be expensive-By the degree of interest for the diet

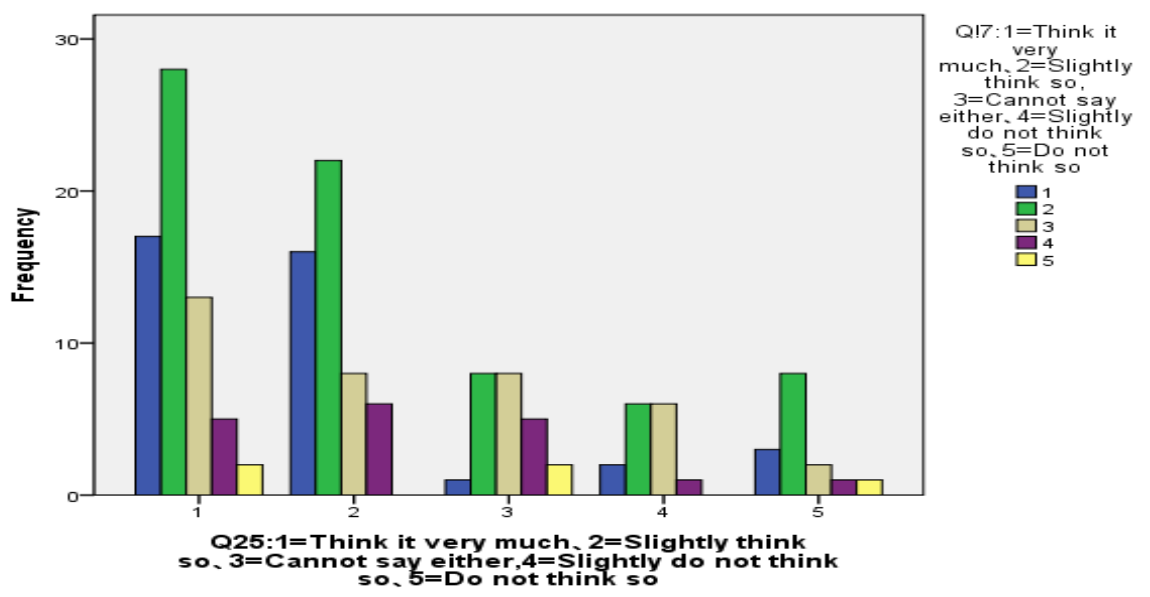

Figure 21. Q17 Seems to be expensive-By the degree of interest for the diet

Those who have interest for the diet feel anxiety that it seems to be expensive. 
d) Q17 Seems to be expensive-By age

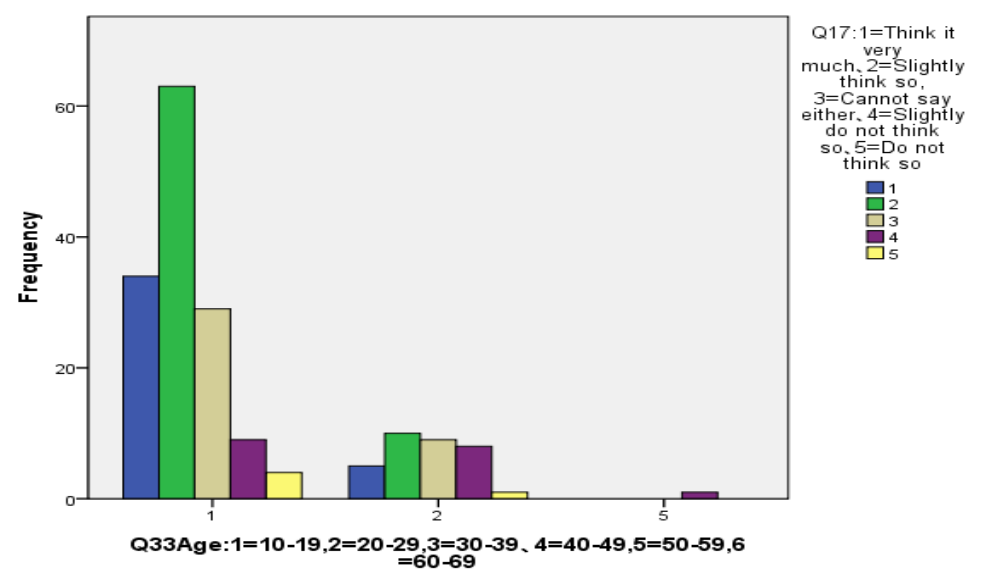

Figure 22. Q17 Seems to be expensive-By age

Those who are young feel anxiety that it seems to be expensive.

e) Q18 Cannot grasp the concrete effect-By Sex

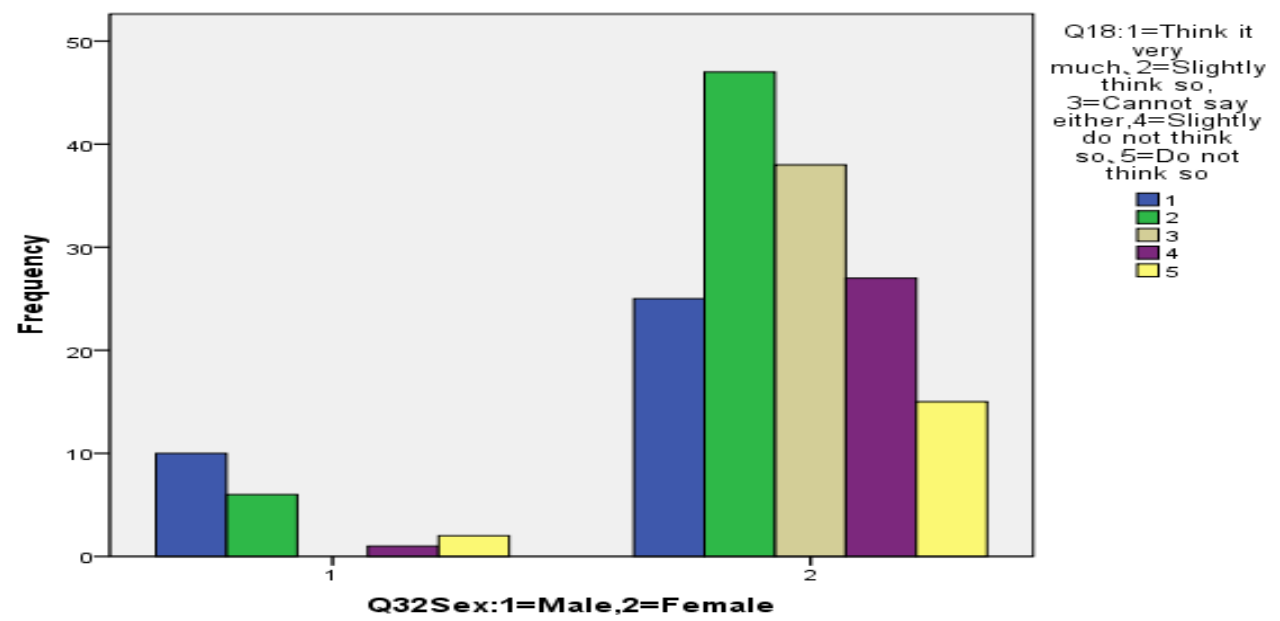

Figure 23. Q18 Cannot grasp the concrete effect-By Sex

Those who are male feel anxiety that they cannot grasp the concrete effect. 
f) Q19 Cannot have confidence that it is safe for anybody-By the degree of interest for the diet

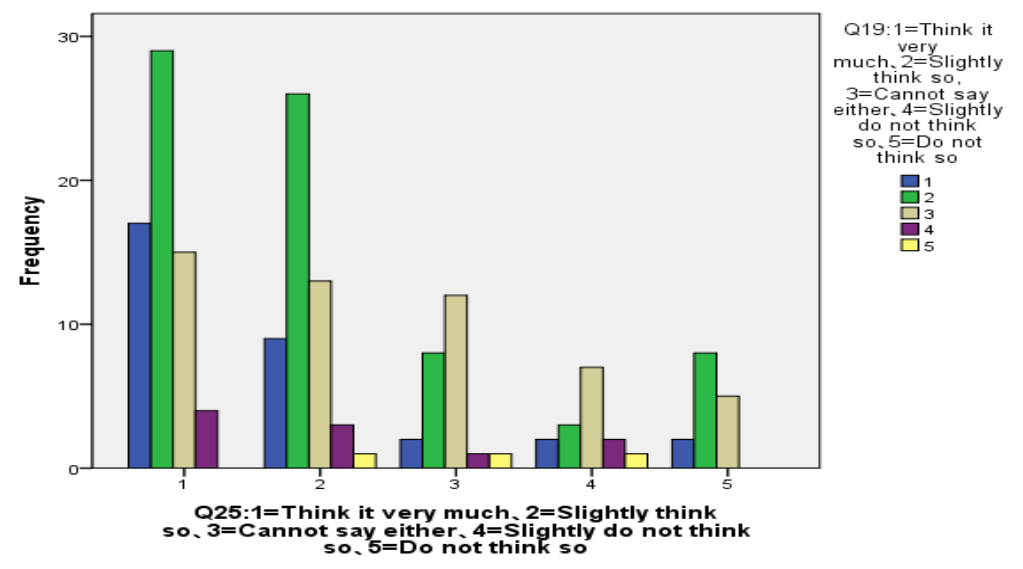

Figure 24. Q19 Cannot have confidence that it is safe for anybody-By the degree of interest for the diet

Those who have interest for the diet cannot have confidence that it is safe for anybody.

g) Q19 Cannot have confidence that it is safe for anybody-By the degree of interest for the health

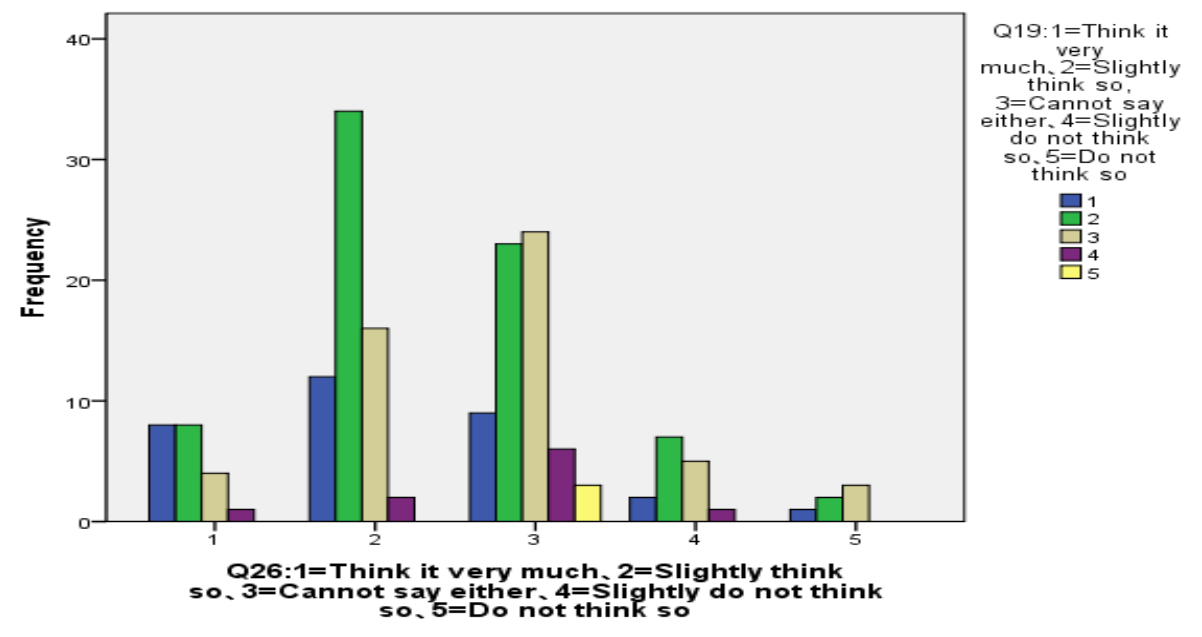

Figure 25. Q19 Cannot have confidence that it is safe for anybody-By the degree of interest for the health

Those who have interest for the health cannot have confidence that it is safe for anybody. 
h) Q20 Surrounding people do not use it so often-By the degree of interest for the diet

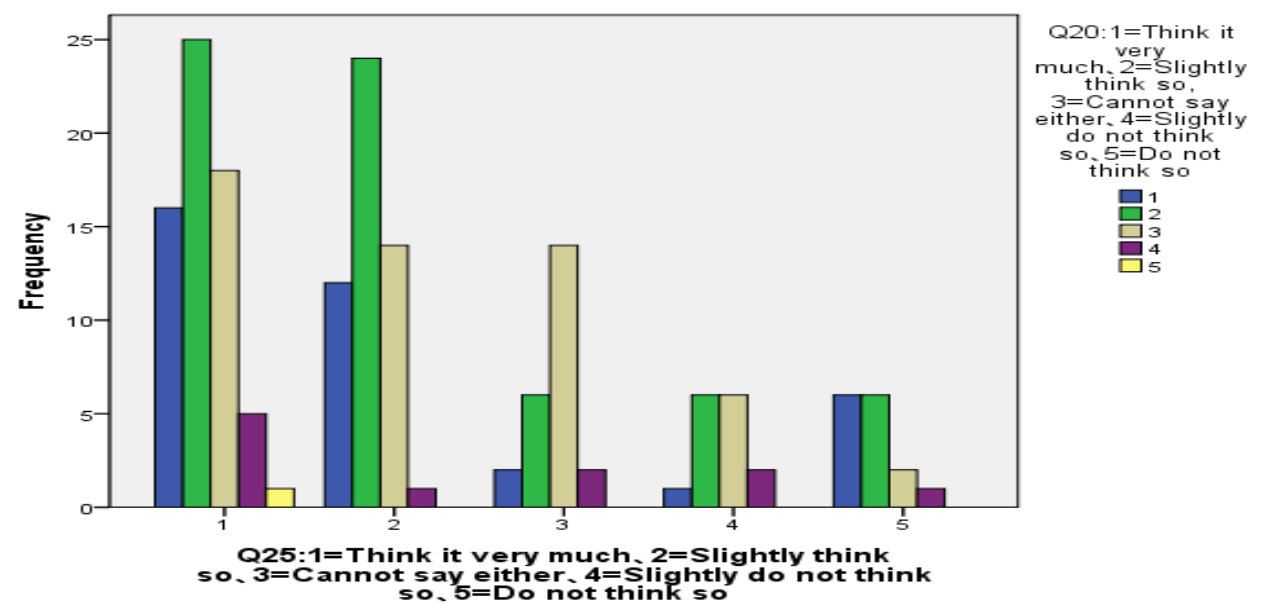

Figure 26. Q20 Surrounding people do not use it so often-By the degree of interest for the diet

Those who have interest for the diet feel anxiety that surrounding people do not use it so often.

i) Q21 Cannot find the food in the shop in which the Rare Sugar is included-By the degree of interest for the diet

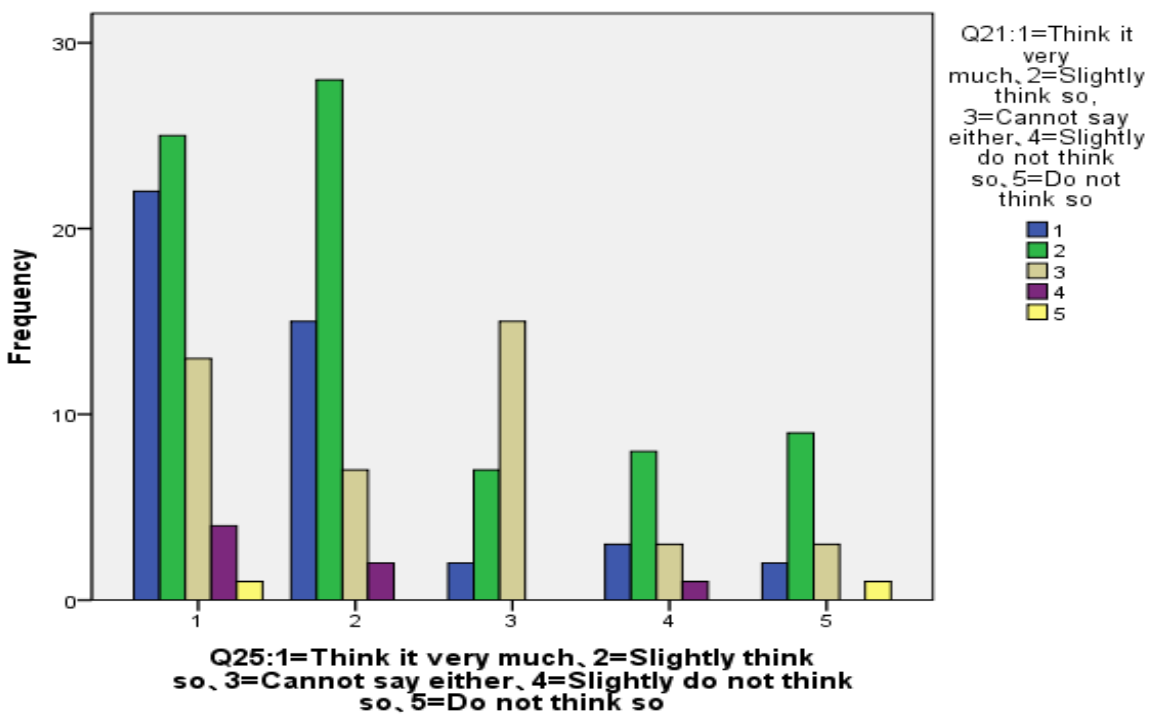

Figure 27. Q21 Cannot find the food in the shop in which the Rare Sugar is included-By the degree of interest for the diet

Those who have interest for the diet feel anxiety that they cannot find the food in the shop in which the Rare Sugar is included. 
j) Q22 Cannot guess how I should use the Rare Sugar to what kind of cooking-By the degree of interest for the diet

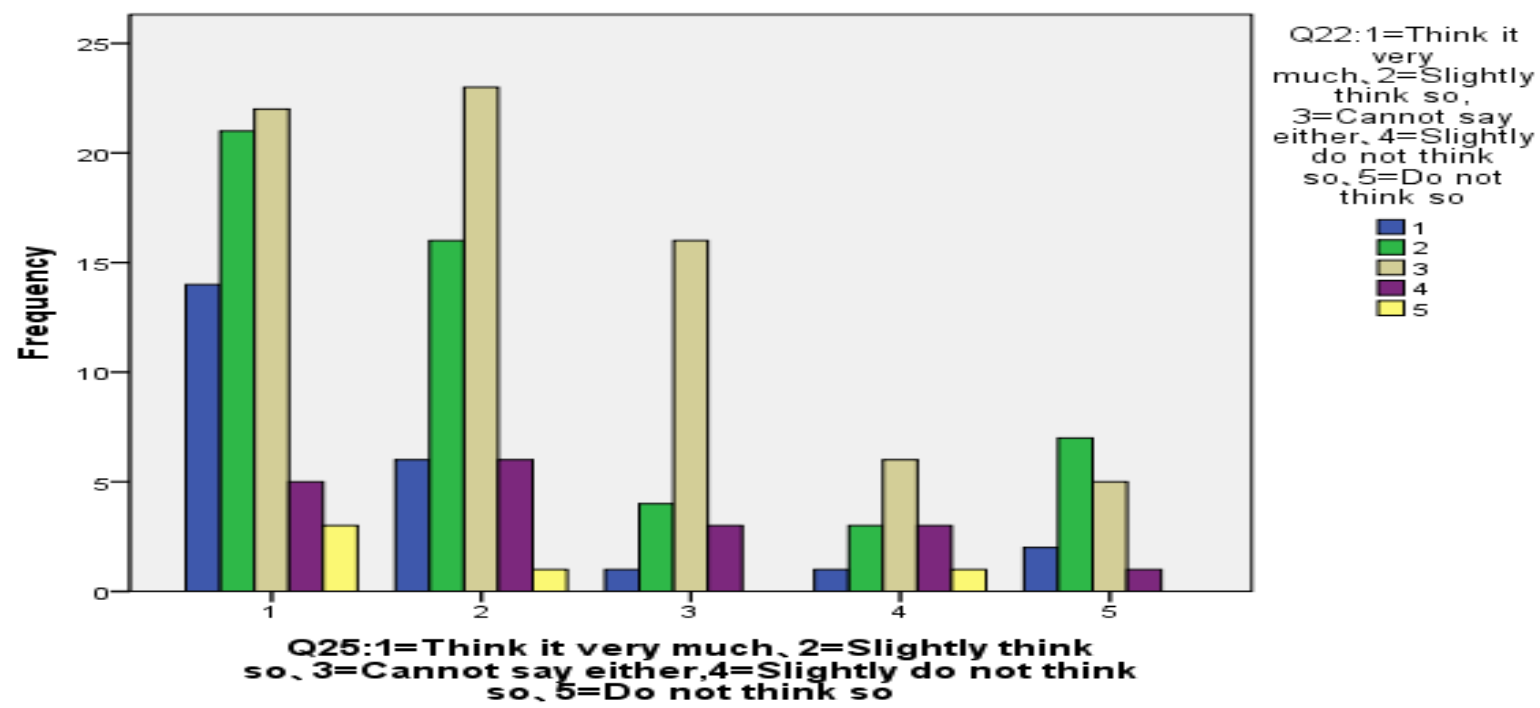

Figure 28. Q22 Cannot guess how I should use the Rare Sugar to what kind of cooking- By the degree of interest for the diet

Those who have interest for the diet feel anxiety that they cannot guess how they should use the Rare Sugar to what kind of cooking.

Q22 Cannot guess how I should use the Rare Sugar to what kind of cooking- By the degree of interest for the health

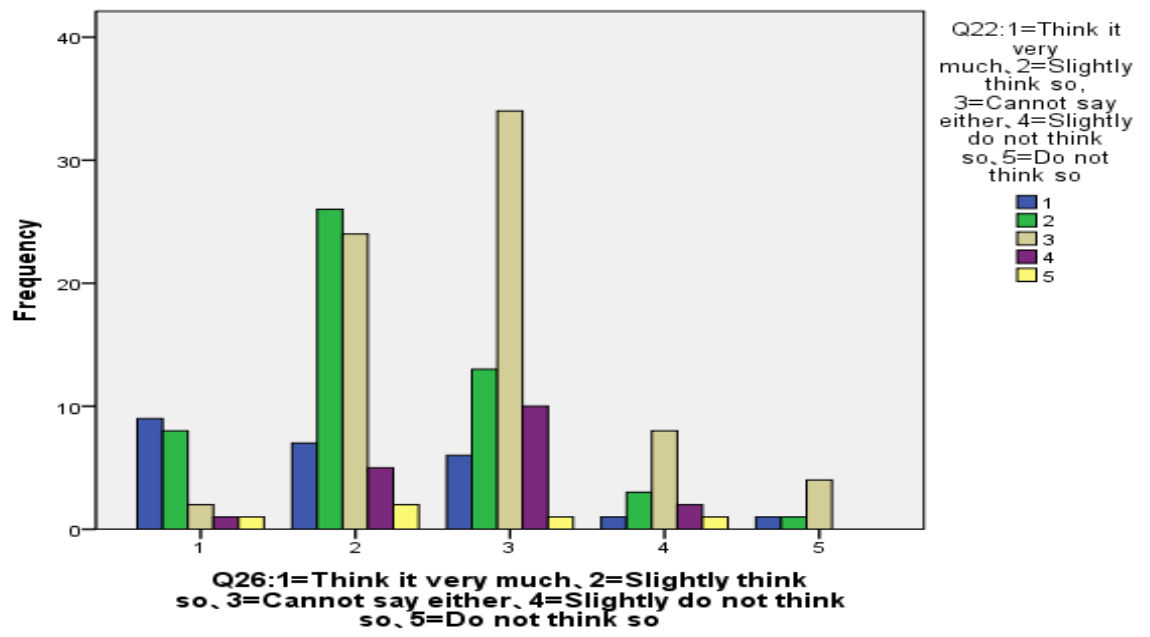

Figure 29. Q22 Cannot guess how I should use the Rare Sugar to what kind of cooking-By the degree of interest for the health

Those who have interest for the health feel anxiety that they cannot guess how they should use the Rare Sugar to what kind of cooking. 
Q22 Cannot guess how I should use the Rare Sugar to what kind of cooking-By Sex

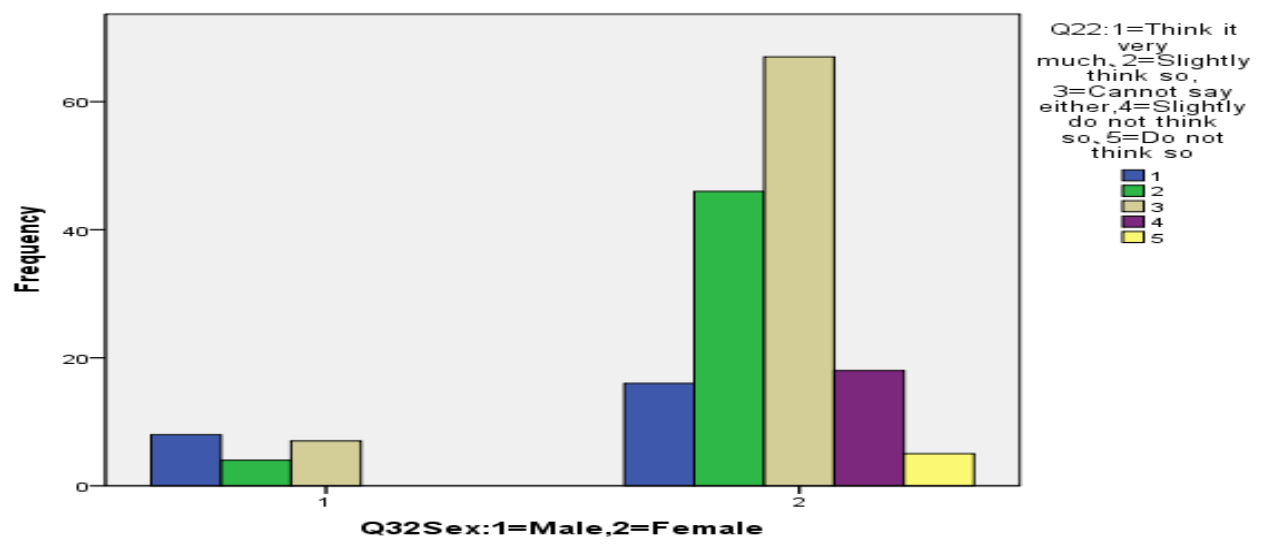

Figure 30. Q22 Cannot guess how I should use the Rare Sugar to what kind of cooking-By Sex

Those who are male feel anxiety that they cannot guess how they should use the Rare Sugar to what kind of cooking.

\section{Conclusion}

The Rare Sugars exist naturally and have many kinds (more than 50). They have good effect for health such as prevention of increasing the blood-sugar level after eating, suppression of fat accumulation, suppression of increasing the blood pressure, and anti-oxidative effect etc. It is in the spotlight for many people especially for those who are in the metabolic syndrome. There are few related papers concerning the marketing research and its utilization of this matter. In this paper, a questionnaire investigation was executed to the student of Kagawa Junior College in order to clarify consumers' current condition and their consciousness, and to seek the possibility of utilizing the Rare Sugars. Fundamental statistical analysis and Non-Parametric Test Analysis were performed.

From the Non-Parametric Test, we could derive the following results.

(1) We can observe that the evaluation of Q7 "Effect of the Rare Sugar" is different by the degree of Q26 "Careful for the health" and we can also confirm that Q4 "Awareness of the "Rare Sugar Sweet"” is different by the degree of interest in the designated health food (Q27).

We can also find that there is a difference in the evaluation of Q1 "Do you know the Rare Sugars?" and Q7 "Was the Rare Sugar effective after using it for more than one month?" by the Sex (Q32). Moreover we can find that there is a difference in Q5 "Have you drunk or eaten the food which includes the Rare Sugar?" by the difference of Q36 "Lifestyle".

(2) We can observe that such users requests as Q10 "Want to use it in the cooking", Q13 "Want to know where I can get information because I want to use it as a supplement", Q14 "Want to know the hospital where the Rare Sugar is used as a tool for treatment" are different by the degree of interest for diet (Q25). And we can observe that such users' requests as Q10 "Want to use it in the cooking", Q12 "Want to know where I can buy it because I want to use it as a seasoning", Q14 "Want to know the hospital where the Rare Sugar is used as a tool for treatment" are different by the degree of interest for the health $(\mathrm{Q} 26)$. We can also find that there is a difference among Q8 "Want to try to eat or drink the food in which the Rare Sugar is included", Q10 "Want to use it in the cooking", Q11 "Can easily use it if there is a recipe" by the degree of interest in the designated health food (Q27).

As for the attribute, there is a difference in Q11 "Can easily use it if there is a recipe" by the difference of age (Q33).

(3) We can observe that such users requests as Q17 "Seems to be expensive", Q19 "Cannot have confidence that it is safe for anybody", Q20 "Surrounding people do not use it so often", Q21 "Cannot find the food in the shop in which the Rare Sugar is included", Q22 "Cannot guess how I should use the Rare Sugar to what kind of cooking" are different by the degree of interest for diet (Q25). We can also find that there is a difference among Q16 "Not so popular", Q18 "Cannot grasp the concrete effect", Q22 "Cannot guess how I should use the Rare Sugar to what kind of cooking" by the degree of interest in the designated health food (Q26). Moreover we can also find that there is a difference in Q22 "Cannot guess how I should use the Rare Sugar to what kind of cooking" by the degree of interest for the health (Q27). 
As for the attribute, there is a difference in Q17 "Seems to be expensive" by the difference of age (Q33).

These are utilized for constructing a much more effective marketing policy. Although it has a limitation that it is restricted in the number of research, we could obtain the fruitful results. To confirm the findings by utilizing the new consecutive visiting records would be the future works to be investigated.

Further study on this should be executed such as Bayesian Network Analysis. Various cases should be investigated here after.

\section{Acknowledgements}

The authors are grateful to all those who supported us for answering the questionnaire investigation.

\section{References}

Hayashi, N., Iida, T., Yamada, T., Okuma, K., Takehara, I., Yamamoto, T., ... Tokuda M. (2010). Study on the postprandial blood glucose suppression effect of D-psicose in borderline diabetes and the safety of long-term ingestion by normal human subjects. Biosci Biotechnol Biochem, 74(3), 510-519. https://doi.org/10.1271/bbb.90707

Hirata, Y., Saito, M., Tsukamoto, I., Yamaguchi, F., Sui, L., Kamitori, K., ... Tokuda, M. (2009, May). Analysis of the inhibitory mechanism of D-allose on MOLT-4F leukemia cell proliferation. J. Biosci Bioeng, 107(5), 562-568. https://doi.org/10.1016/j.jbiosc.2008.12.021

Hossain, M.A., Kitagaki, S., Nakano, D., Nishiyama, A., Funamoto, Y., Matsunaga, T., ... Tokuda M. (2011, Feburary). Rare sugar D-psicose improves insulin sensitivity and glucose tolerance in type 2 diabetes Otsuka Long-Evans Tokushima Fatty (OLETF) rats. Biochem Biophys Res Commun, 405(1), 7-12. https://doi.org/10.1016/j.bbrc.2010.12.091

Iida, T., Hayashi, N., Yamada, T., Yoshikawa, Y., Miyazato, S., Kishimoto, Y., ... Izumori, K. (2010). Failure of d-psicose absorbed in the small intestine to metabolize into energy and its low large intestinal fermentability in humans. Metabolism, 59(2), 206-214. https://doi.org/10.1016/j.metabol.2009.07.018

Kajikawa, T., Tada, S., Kitanaka, A., Tokuda, M., \& Taminat, T. (2010). Reactivity of rare sugar D-allose during glycation of human serum albumin. J. Analy Bio-Sci., 33(3), 227-236.

Mitani, T., Hoshikawa, H., Mori, T., Hosokawa, T., Tsukamoto, I., Yamaguchi, F., ... Mori, N. (2009, August). Growth inhibition of head and neck carcinomas by D-allose. Head Neck, 31(8), 1049-1055.

Miyanishi, N., Sato, N., Nakakita, S., Sumiyoshi, W., Morimoto, K., Okuma, H., .. Hirabayashi, J. (2008, April). Development of an amperometric flow analysis sensor for specific detection of D-psicose. Biosens Bioelectron, 23(9), 1347-1352. https://doi.org/10.1016/j.bios.2007.12.003

Murao, K., Yu, X., Cao, W.M., Imachi, H., Chen, K., Muraoka, T., ... Ishida, T.D. (2007, July). Psicose inhibits the expression of MCP-1 induced by high-glucose stimulation in HUVECs. Life Sci., 81(7), 592-599. https://doi.org/10.1016/j.lfs.2007.06.019

Nakamura, T., Tanaka, S., Hirooka, K., Toyoshima, T., Kawai, N., Tamiya, T., ... Miyamoto, O. (n.d). Anti-oxidative effects of D-allose, a rare sugar, on ischemia-reperfusion damage following focal cerebral ischemia in rat.

Sui, L., Nomura, R., Dong, Y., Yamaguchi, F., Izumori, K., \& Tokuda, M. (2007, Octomber). Cryobiology Cryoprotective Effects of D-allose on Mammalian Cells, 55(2), 87-92. https://doi.org/10.1016/j.cryobiol.2007.05.003

Suna, S., Yamaguchi, F., Kimura, S., Tokuda, M., Jitsunari, F. (2007, September). Preventive effect of D-psicose, one of rare ketohexoses, on di-(2-ethylhexyl) phthalate (DEHP)-induced testicular injury in rat. Toxicol Lett, 173(2), 107-117. https://doi.org/10.1016/j.toxlet.2007.06.015

Yamada, K., Noguchi, C., Kamitori, K., Dong, Y., Hirata, Y., Hossain, M.A., ... Yamaguchi F. (2012, Feburary). Rare sugar d-allose strongly induces thioredoxin-interacting protein and inhibits osteoclast differentiation in Raw264 cells. Nutr Res, 32(2), 116-123. https://doi.org/10.1016/j.nutres.2011.12.010

Yamaguchi, F., Kamitori, K., Sanada, K., Horii, M., Dong, Y., Sui, L., \& Tokuda, M. (2008, September). Rare sugar D-allose enhances anti-tumor effect of 5-fluorouracil on the human hepatocellular carcinoma cell line HuH-7. $J$ Biosci Bioeng, 106(3), 248-252. https://doi.org/10.1263/jbb.106.248

Yamaguchi, F., Takata, M., Kamitori, K., Nonaka, M., Dong, Y., Sui, L., \& Tokuda, M. (2008, February). Rare sugar D-allose induces specific up-regulation of TXNIP and subsequent G1 cell cycle arrest in hepatocellular carcinoma cells by stabilization of p27kip1. Int J Oncol, 32(2), 377-385. 


\section{Appendix. Questionnaire about the Rare Sugars}

\section{Questionnaire about the Rare Sugars}

The Rare Sugars exist naturally and have many kinds (morethan 50). They have good effect for health such as prevention of increasing the a blood-sugar level after eating, suppression of fat accumulation, suppression of increasing the blood pressure, and antioxidative effect etc. It is in the spotlight for many people especially for those who are in the metabolic syndrome

Please select the appropriate item in each column.(Plural answers are allowed for Q2, 9, 24, 28. Select (1) (5) in the right colum for Q7, 8, 10-23, 25-27.)

1.We ask you about the Rare Sugars.

1-1. Do you know the Rare Sugars?

Q1 $\quad$ (1)Know (2)Do not know ( $\Rightarrow$ Proceed to Q8 who has selected (2) and answer until to the last.)

1-2. We ask you who have selected (1). Where did you know the Rare Sugar?【Plural answers are allowed】

Q2 (1)TV (2)Magazine (3)Newspaper (4)Shop (5)Vending Machine (6)Seminar (7)Internet (8)Hear from another person (9)Miscellaneous ( )

1-3. Do you know that the Rare Sugar has effect on obese prevention and/or diabetes prevention etc.?

Q3 (1)Know (2)Do not know

1-4. Have you heard or used the syrup which includes Rare Sugar "Rare Sugar Sweet"?

Q4 (1)Heard (2)Not heard

Q5 (1)Used (2)Not used

1-5. Have you drunk or eaten the food which includes the Rare Sugar?

Q6 1 (1) Yes (2) No

Q7 1-6. We ask you who have selected (1) in Q6. Was the Rare Sugar effective after using it for more than one

month? ( $\Rightarrow$ Proceed to Q9)

Q8 1-7. We ask you who have selected (2) in Q1,(2) in Q6. Do you want to try to eat or drink the food in which the Rare Sugar is included?

1-8. What kind of food do you want to eat if the Rare Sugar is included?【Plural answers are allowed】

Q9 1 (1) Cake (2)Juice (3)Japanese food (4)Western food (5)Chinese food (6)Miscellaneous ( 1-9.How do you want to use the Rare Sugar?

Q10 a. I want to use it in the cooking.

Q11 b. I can easily use it if there is a recipe.

Q12 c. I want to know where I can buy it because I want to use it as a seasoning.

Q13 d. I want to know where I can get information because I want to use it as a supplement.

Q14 e. I want to know the hospital where the Rare Sugar is used as a tool for treatment.

Q15 f. I want to know how long I should use it in order to confirm the effectiveness. 1-10.Do you have a question(doubt) or anxiety for the Rare Sugar?

Q16 a. It is not so popular.

Q17 b. It seems to be expensive.

Q18 c. I cannot grasp the concrete effect.

Q19 d. I cannot have confidence that it is safe for anybody.

Q20 e. Surrounding people do not use it so often.

Q21 f. I cannot find the food in the shop in which the Rare Sugar is included.

Q22 g. I cannot guess how I should use the Rare Sugar to what kind of cooking?

Q23 h. Miscellaneous( )

\begin{tabular}{||l|l|l|l|l|}
\hline $\begin{array}{l}\text { (1) Think it } \\
\text { very much }\end{array}$ & $\begin{array}{l}\text { (2)Slightly } \\
\text { think so }\end{array}$ & $\begin{array}{l}\text { (3)Cannot } \\
\text { say either }\end{array}$ & $\begin{array}{l}\text { (4)Slightly do } \\
\text { not think so }\end{array}$ & $\begin{array}{l}\text { 5)Do not } \\
\text { think so }\end{array}$ \\
\hline $\begin{array}{l}\text { (1) Think it } \\
\text { very much }\end{array}$ & $\begin{array}{l}\text { (2)Slightly } \\
\text { think so }\end{array}$ & $\begin{array}{l}\text { (3)Cannot } \\
\text { say either }\end{array}$ & $\begin{array}{l}\text { (4)Slightly do } \\
\text { not think so }\end{array}$ & $\begin{array}{l}\text { 5)Do not } \\
\text { think so }\end{array}$ \\
\hline
\end{tabular}
\begin{tabular}{|l|l|l|l|l|}
$\begin{array}{l}\text { (1) Think it } \\
\text { very much }\end{array}$ & $\begin{array}{l}\text { (2) Slightly } \\
\text { think so }\end{array}$ & $\begin{array}{l}\text { (3) Cannot } \\
\text { say either }\end{array}$ & $\begin{array}{l}\text { (4) Slightly do } \\
\text { not think so }\end{array}$ & $\begin{array}{l}\text { (5)Do not } \\
\text { think so }\end{array}$ \\
\hline
\end{tabular}

1-11.Choose the drink that you are interested in.【Plural answers are allowed】

Q24 (1)aojiru (2)OS-1(oral rehydration solutionDrink for sports) (4)designated health drink (5)drink with the Rare Sugar (6)None (7)Miscellaneous (

Q25 1-12. Do you take interest in a diet?

Q26 1-13. Are you careful for the health?

Q27 1-14. Do you take interest in the designated health food?

1-15. Which method would be suitable for the Rare Sugar to become popular?

(1)TV CM (2)Use Twitter,Facebook (3)Advertisement by the company (4)Spread the way of cooking (5)Sell candy with the Rare Sugar

Q28 (6)Sell juice with the Rare Sugar (7)Restaurant at which the Rare Sugar is used in the cooking (8)Use it in the food at the hospital (9)Sell it as a supplement (10Make promotion by utilizing famous sportsmen or entertainers (11)Miscellaneous (

2.What is your hobby? (Select only one in the right hand column)

Q29 2-1.Playing Sports: (1)Baseball (2)Football (3)Tennis (4)Golf (5)Miscellaneous ( )

Q30 2-2. Watching Sports: (1)Baseball (2)Football (3)Tennis (4)Golf (5)Miscellaneous ( )

Q31 2-3. Drinking: (1)Beer (2)Wine (3)Japanese wine-sake (4)Japanese liquor-shochu (5)Whisky

Q31 6)Miscellaneous ( )

\begin{tabular}{|c|c|c|c|c|}
\hline $\begin{array}{l}\text { (1) Think it } \\
\text { very much }\end{array}$ & $\begin{array}{l}\text { (2)Slightly } \\
\text { think so }\end{array}$ & $\begin{array}{l}\text { (3) Cannot } \\
\text { say either }\end{array}$ & $\begin{array}{l}\text { (4) Slightly do } \\
\text { not think so }\end{array}$ & \begin{tabular}{|l} 
(5)Do not \\
think so
\end{tabular} \\
\hline $\begin{array}{l}\text { (1) Think it } \\
\text { very much }\end{array}$ & $\begin{array}{l}\text { (2)Slightly } \\
\text { think so }\end{array}$ & $\begin{array}{l}\text { (3) Cannot } \\
\text { say either }\end{array}$ & $\begin{array}{l}\text { (4) Slightly do } \\
\text { not think so }\end{array}$ & \begin{tabular}{|l} 
(5)Do not \\
think so
\end{tabular} \\
\hline $\begin{array}{l}\text { (1) Think it } \\
\text { very much }\end{array}$ & $\begin{array}{l}\text { (2) Slightly } \\
\text { think so }\end{array}$ & $\begin{array}{l}\text { (3) Cannot } \\
\text { say either }\end{array}$ & $\begin{array}{l}\text { (4) Slightly do } \\
\text { not think so }\end{array}$ & \begin{tabular}{|l|}
$\begin{array}{l}\text { (5)Do not } \\
\text { think so }\end{array}$ \\
\end{tabular} \\
\hline
\end{tabular}

(1)Like it (2)Slightly (3)Ordin \begin{tabular}{|l|l|l|l} 
very much & like it & level \\
\hline $\begin{array}{l}\text { (1)ike it } \\
\text { very much }\end{array}$ & $\begin{array}{l}\text { (2) Slightly } \\
\text { like it }\end{array}$ & $\begin{array}{l}\text { 3) Ordina } \\
\text { level }\end{array}$ \\
\hline
\end{tabular} \begin{tabular}{|l|l|l}
$\begin{array}{l}\text { (1) Like it } \\
\text { very much }\end{array}$ & $\begin{array}{l}\text { (2)Slightly } \\
\text { like it }\end{array}$ & $\begin{array}{l}\text { (3)Or } \\
\text { level }\end{array}$
\end{tabular} 
3. We ask you questions about your current condition.

Q32 3-1. Sex: (1)Male (2)Female

Q33 3-2. Age: (1) 19 (2) $20 \sim 29$ (3) $30 \sim 39$ (4) $40 \sim 49$ (5) $50 \sim 59$ (6) More than 60

Q34 3-3. Occupation: (1)Student (2)Officer (3)Company Employee (4)Clerk of Organization (5)Independents (6)Part-timer (7)Housewife (8)Miscellaneous(

Q35 3-4. Address: (1)Prefecture( ) (2)City(

Q36 3-5. What kind of lifestyle do you like?: (1)Outdoor (2)Indoor (3)Not either 